\title{
Skills for Diversity: Description, Evaluation and Recommendations
}

Eric S. Janus

Mitchell Hamline School of Law, eric.janus@mitchellhamline.edu

Follow this and additional works at: https://open.mitchellhamline.edu/facsch

Part of the Legal Education Commons

Publication Information

Unpublished

\section{Repository Citation}

Janus, Eric S., "Skills for Diversity: Description, Evaluation and Recommendations" (1992). Faculty Scholarship. 478.

https://open.mitchellhamline.edu/facsch/478

This Article is brought to you for free and open access by Mitchell Hamline Open Access. It has been accepted for inclusion in Faculty Scholarship by an authorized administrator of Mitchell Hamline Open Access. For more information, please contact sean.felhofer@mitchellhamline.edu.

\section{$\mathrm{MH}$}

MITCHELL | HAMUINE OPEN ACCESS

selod for the

mitchellhamline.edu 


\title{
Skills for Diversity: Description, Evaluation and Recommendations
}

\begin{abstract}
In May 1991, the William Mitchell College of Law Faculty voted to offer to all first year students the following fall a program to assist students "in learning how to work effectively with diverse others in professional situations." The faculty directed that the program be supervised by a member of the full time faculty, and that reaction to the program be evaluated by the Curriculum Committee. During the Summer 1991, the dean appointed me to supervise the program, and I asked Assistant Dean Joan Bibelhausen to assist me. The two of us worked closely with an informal group called the NCBI Trainers Group to plan and execute the Program.
\end{abstract}

I have prepared this Report to the Curriculum Committee in consultation with Assistant Dean Bibelhausen and the NCBI Trainers Group. The Report proceeds in the following manner. First, the Report sketches the history leading up to the faculty's adoption of the Program. Second, the Report describes the planning and contents of the Program. Third, the Report evaluates the Program. Fourth, the Report offers recommendations for future educational work on diversity at William Mitchell College of Law.

\section{Keywords}

Diversity training, William Mitchell School of Law, Legal Education

\section{Disciplines}

Legal Education 


\section{SKILLS FOR DIVERSITY: DESCRIPTION, EVALUATION AND RECOMMENDATIONS}

ERIC S. JANUS

APRIL 30, 1992

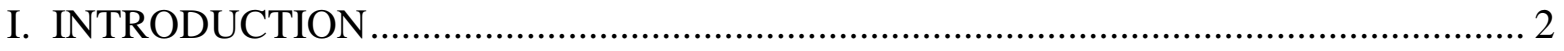

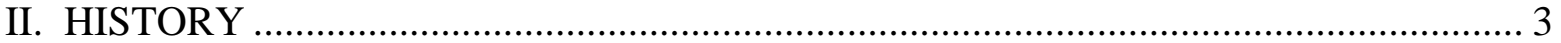

A.. MMLA and Transition/Implementation Committee ................................................... 3

B. Faculty and Faculty Minority Affairs Committee...................................................... 4

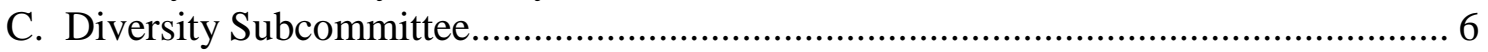

III. PLANNING AND PRESENTING THE PROGRAM ……………………….............. 9

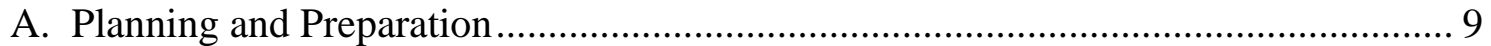

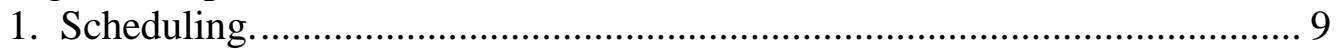

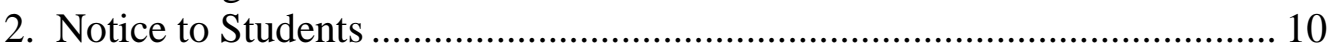

3. Name, content, and leaders …………................................................. 12

B. Description of Content and Purposes of the NCBI Workshop ................................... 14

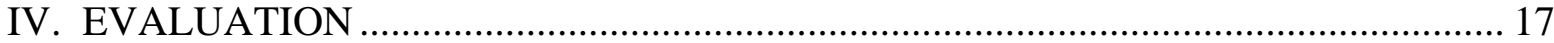

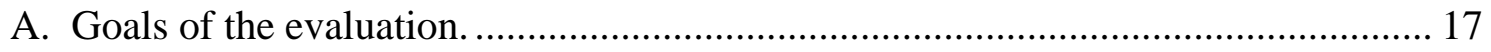

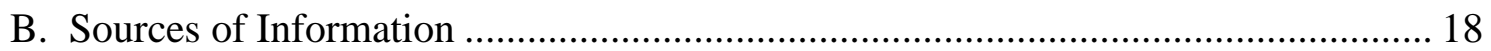

C. Evaluation of Program Content ……………………….......................................... 19

1. Participants' evaluations of the workshop................................................... 19

2. Reasons Participants Left the Program Early............................................... 25

3. Data from Participants in Previous Workshops ………………………….... 26

4. Assessment of Participant Reaction........................................................... 27

D. Evaluation of Outreach Efforts ............................................................................. 30

1. Demographics of Participants ................................................................. 30

2. Reasons why participants chose to attend................................................... 32

3. Reasons why students chose not to attend .................................................. 33

4. Evaluation of the Data on Outreach .............................................................. 49

E. Evaluation of Coercion, Pressure, Political and emotional Content, and Warnings of

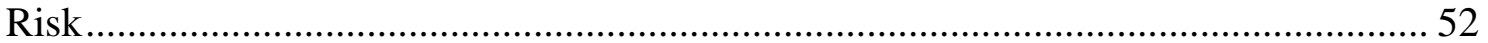

1. Pressure and coercion as factors in attendance decisions ........................... 52

2. Political and emotional content as factors in attendance decisions.............. 52

3. Pressure, coercion, politics and emotion as perceived by participants ........ 53

4. Assessment of pressure, coercion, political and emotional content and warnings of risk........................................................................................ 54

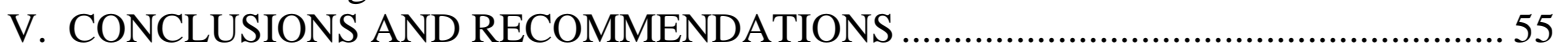

A. Effectiveness and suitability of the program: …………………………………..... 55

B. Coercion, pressure, emotional distress, politics......................................................... 56

C. Disclaimers, warnings of risk, content of notice ……………………..................... 57

D. Level of attendance.......................................................................................... 58

E.. Attaining maximum participation with an optional program during class time....... 59

F. Mandatory versus optional: Academic Freedom, Coercive Learning and Effective 
Education

61

G. Models for Incorporating Diversity Education into the Core Curriculum ............... 62

1. Model I. A "CLE" Approach. .................................................................. 62

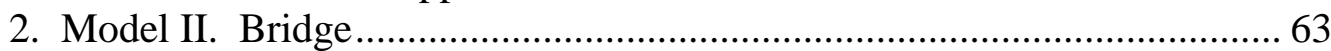

3. Model III. Integration into a required "lawyering skills" course .............. 63

H.. Extra-curricular training

\section{INTRODUCTION}

In May 1991, the William Mitchell College of Law Faculty voted to offer to all first year students the following fall a program to assist students "in learning how to work effectively with diverse others in professional situations." The faculty directed that the program be supervised by a member of the full time faculty, and that reaction to the program be evaluated by the Curriculum Committee. During the Summer 1991, the dean appointed me to supervise the program, and I asked Assistant Dean Joan Bibelhausen to assist me. The two of us worked closely with an informal group called the NCBI Trainers Group ${ }^{1}$ to plan and execute the Program.

I have prepared this Report to the Curriculum Committee in consultation with Assistant Dean Bibelhausen and the NCBI Trainers Group. ${ }^{2}$ The Report proceeds in the following manner. First, the Report sketches the history leading up to the faculty's adoption of the Program. Second, the Report describes the planning and contents of the Program. Third, the Report evaluates the Program. Fourth, the Report offers recommendations for future educational work on diversity at William Mitchell College of Law.

\footnotetext{
${ }^{1}$ See below for a description of this group.

${ }^{2}$ In addition, I received helpful comments from Dean Jim Brooks and Prof. Dan Kleinberger
} 


\section{HISTORY}

Several factors led to the faculty action in Spring 1991 adopting the Skills for Diversity program. During the late 1980's issues of race, gender, sexual orientation and other aspects of "difference" began to assume increased importance in national discussions of higher education. For example, this topic was the central theme of the AALS meetings in January 1990.

Discussions focused on faculty hiring and retention, curriculum, and law school environment.

Simultaneously, the William Mitchell community was focused intensively on these issues. Forming the background for this activity were a sexual harassment case in 1983-84, and more contemporaneous faculty employment matters involving allegations of race and sex discrimination, both of which were resolved in 1990. To understand the events leading up to the faculty action which is the subject of this Report, one must examine three threads:

- The Minnesota Minority Lawyers Association boycott of the school and the subsequent formation of a joint committee to assist the school in working on diversity issues.

- The work of the College faculty and its Minority Affairs Committee.

- The work of the College's Diversity Subcommittee.

\section{A.. MMLA and Transition/Implementation Committee}

In January 1990, the Minnesota Minority Lawyers Association issued a report about the detenuring of Prof. Andrew Haines. In a press release accompanying the report, the MMLA stated, "William Mitchell remains insensitive to issues of racial and gender discrimination. Until fundamental changes are made at William Mitchell to resolve these problems, MMLA recommends that minority faculty and students not teach or attend William Mitchell College of Law." Among the recommendations MMLA made in its report was the following:

The implementation of mandatory race and gender relations sensitization programs and seminars for the Board of Trustees, Administrators, staff, faculty, and students.

In late spring of 1990, MMLA and the College (acting through the Dean of the College) entered into a Memorandum of Understanding which set forth a course of action for the College in a number of areas related to diversity. As relevant here, the Memorandum provided:

Required seminars and programs for recognizing and removing race and gender bias are scheduled to begin in the spring of 1990 for faculty, staff, administrators, and students. The faculty, students and administration also strongly recommend that the Board of Trustees attend race and gender sensitization programs that are made available to the faculty, staff, 
administration and students at WMCL.

Pursuant to the Memorandum, a Transition/Implementation committee was established and began meeting in the summer of 1990. The membership of this Committee, which was specified in the Memorandum of Understanding, comprised people from MMLA, the William Mitchell faculty and Administration, and current and former students of WMCL. The purpose of the committee was to assist the College in implementing the terms of the Memorandum of Understanding. ${ }^{3}$ One thread of the work of the committee concerned the above-cited recommendation on training and education. The committee's work on that resulted in a recommendation addressed to the Board of Trustees, dated August 18,1991, as follows:

The College should continue to make available broad-based training on the topic of welcoming diversity. This training should reach all incoming students and a growing number of existing students. Training should focus on coalition building, empathy development, development of effective skills for understanding and welcoming difference, and addressing intolerance. ${ }^{4}$

The Board of Trustees approved a Report and Recommendations of its Ad Hoc Committee which had reviewed the Transition/Implementation Committee's Report. The Ad Hoc Committee's report contained the following material on "Education and Training":

Significant efforts have been undertaken by the College to provide sensitivity training for faculty, staff, students and members of the Board. As indicated in the long-range planning documentation as well as in the Statement of Strategic Diversity Goals, both the Board and the administration have indicated their intention to continue sensitivity training. ... The Dean is supportive of effective sensitivity training for students just as he has supported such training for faculty, staff and members of the Board. ...

\section{B. Faculty and Faculty Minority Affairs Committee}

In the Fall of 1989, the Faculty Minority Affairs Committee began working on a set of goals for diversity. These goals were eventually presented to the full faculty, which adopted them in May 1990. Among the goals adopted by the faculty were:

\footnotetext{
${ }^{3}$ See Memorandum of Understanding.

${ }^{4}$ The Report noted that the terms of the Memorandum of Understanding relating to training and education were "somewhat vague". It interpreted the provision of the Memorandum of Understanding as being "aimed at ameliorating concerns about the environment for minority persons and women at WMCL. The Report noted that the Memorandum of Understanding spoke in terms of "'required"' seminars and programs, and noted that attendance had not been required at any of the seminars and programs already held. The Report indicated that it did not find this fact to be a basis for a finding of non-compliance with the Memorandum of Understanding because the programming had, in fact, "reached a substantial proportion of its intended audiences."
} 
Creating an environment for persons of color, women, gays and lesbians, persons with diverse religious persuasions, older persons, and persons with disabilities, which is nurturing and welcoming.

Increasing the level of understanding, among all segments of the community, of the nature and history of racism, sexism, homophobia, religious intolerance, age and disability discrimination, and of the value to the institution, the profession, and the society of decreasing and eliminating these forms of intolerance and of increasing diversity.

Creating an environment in which issues of race, gender, sexual orientation, age and ability can be discussed freely and safely, without fear of reprisal.

Incorporating into the curriculum significant and meaningful materials on the relationship of law to race, gender, sexual preference intolerance and bias, religious intolerance, age and disability discrimination and their eradication.

In February, 1990, the Dean delegated to the Minority Affairs Committee the job of planning, coordinating and executing the College's efforts to meet these goals. ${ }^{5}$ Pursuant to this delegation, the Committee sponsored a series of four lectures by Prof. Robert Terry of the University of Minnesota Humphry Institute on racism during the Spring of 1990. During the Summer of 1990, the Committee planned and executed a program for diversity during new student orientation. In October 1990, the Committee sponsored a 12-hour workshop led by Cherie Brown and Arlene Allan of the National Coalition Building Institute (NCBI), then located in Boston. This workshop was designed to train participants to lead workshops in "prejudice reduction" using the program and methods developed by Cherie Brown and the NCBI. The program was open to all members of the WMCL community, and was attended by about 40 faculty, administrators, staff and students.

Many of the participants in the workshop continued to meet on a regular basis as the NCBI Trainers Group. This group practiced the NCBI method and planned future workshop offerings. A series of workshops was offered in the Spring of 1991. One, led by Cherie Brown and Airline Allan was attended mostly by faculty and students. Two other workshops were led by WMCL

\footnotetext{
${ }^{5}$ The Dean wrote a memo to the Minority Affairs Committee on February 7, 1990. In the memo, he requested that the Minority Affairs Committee engage in the planning and coordination of a variety of issues regarding "diversity and tolerance." In particular, the Dean noted that the "broad base of organizations and groups represented on the Minority Affairs Committee makes your committee the ideal coordinating entity." Subsequently, a variety of other groups has become involved in the planning, coordination and evaluation of the College's diversity efforts. As set forth in Dean Hogg's memorandum of April 20, 1992, these include "the Strategic Planning Task Force (planning for implementation of the [Diversity Strategic] goals), the College Relations and Diversity Committee (oversight of performance with respect to those goals), and various offices within the Administration ....”
} 
people and attracted mostly students. In total, about 120 people attended the four workshops given during the 1990-91 school year.

\section{Diversity Subcommittee}

In late fall 1990, the College Relations Committee of the Board of Trustees established a Diversity Subcommittee. The Diversity Subcommittee was charged with the task of developing a Comprehensive Diversity Plan. The Committee's members came from each of the College constituencies (Trustees, Faculty, Staff, Students). The Subcommittee held its first meeting in November 1990. Working through sub- subcommittees, the Committee developed a series of recommended goals and objectives. The sub-subcommittee on curriculum, in a draft dated April 18, 1990, suggested the following "desired outcome" of the school's educational program:

Graduates who can function effectively in a diverse profession, judiciary and society.

Graduates who respect and understand a diversity of voices and views of the law and the legal profession.

Graduates who have skills to work with diverse others.

Graduates who understand the place of law and the legal profession in both producing and removing various forms of oppression.

The sub-subcommittee set out proposed activities to accomplish these goals.

Among those were, as relevant here:

As a short range goal, providing, as part of the core curriculum, training to all students in working effectively with diverse others in professional situations. This curricular offering could be based on the NCBI model which has been used in pilot training at WMCL for the past year.

The May 8 draft of the Subcommittee's Plan included the sub-subcommittee's proposal in somewhat modified form. Among the curriculum goals listed was the following:

WMCL should produce graduates who can function effectively in a diverse profession, judiciary and society. These skills include:

a) Openness on issues of diversity.

b) Reflective critical thinking.

c) Deliberative dialog.

d) Imaginative empathy. 
The curriculum should be designed to turn out graduates who respect and understand a diversity of voices and views of the law and the legal profession. The curriculum should also be aimed at instilling those skills necessary to work with diverse others. The curriculum should be designed to produce graduates who understand the place of law and the legal profession in both producing and removing various forms of bias, discrimination, and oppression.

WMCL should foster a learning environment which eschews blame and guilt, ideology, indoctrination and coercive intimidation as educational methods, and seeks to develop an open, non-defensive understanding of the nature of racism, sexism and other forms of bias.

A portion of the recommendation was forwarded to the Curriculum Committee of the

Faculty. The recommendation was amended and forwarded to the entire faculty in the following form:

The College will offer a program to all first-year students for the purpose of assisting them in learning how to work effectively with diverse others in professional situations. This offering will be based on the NCBI model used in pilot training at WMCL during the 1990-91 academic year. The program will be implemented by the College's NCBI Trainers' Group, supervised by the Assistant Dean of Career Services. It will be offered during students' regular class hours, and the pre-empted classes will be rescheduled for make-up at the end of the semester. Students will be told in advance of the program that while the program is highly recommended, attendance is not required. The program will not exceed six hours. The Curriculum Committee will evaluate the reaction to the program and report back to the faculty.

After discussion, the faculty adopted the recommendation. ${ }^{6}$ The major issues discussed at the faculty curriculum committee and the full faculty concerned:

\section{a. Whether the program would be mandatory.}

Opinion fell into three categories on this subject. Some felt the importance of the message in the program dictated that it should be mandatory. Some felt that the program was important and might merit being mandatory, but that given the novelty of it and our inexperience at offering such programs, it should not be. Some felt that making the program mandatory would

\footnotetext{
${ }^{6}$ In addition, the faculty adopted a set of Diversity Strategic Goals on May 29 and 30, 1992. Three of those goals are relevant here:

The College will foster an environment of mutual respect, openness and consideration, free of discrimination based on race, color, creed, ethnic origin, national origin, gender, religion, sexual orientation, marital status, status with regard to public assistance, age or disability.

The College's curriculum will provide opportunities for its students to acquire the understanding and legal skills to work effectively in a diverse society.

The College will encourage members of the College community to help develop a legal system, legal profession, and community in which differences among persons are respected.
} 
be tantamount to adopting an institutional "orthodoxy" on the sensitive issues of diversity, and thus should be avoided.

One member of the Diversity Subcommittee raised concerns about these proposals. Commenting that the proposal "need substantial clarification to have meaning," he spelled out his concern as follows:

My principal fear with respect to implementation of both the environmental and the curricular goals is that we will substitute ideology, indoctrination, and coercive intimidation for our traditional educational process where students (1) are presented with examples of different, often opposing views, (2) are taught analytical and other skills with which to address such views, and (3) are expected to reach by themselves conclusions which they may wish to live by and implement. ${ }^{7}$

b. Whether the program would be offered during class hours, and, if so, whether the class hours displaced for the program would be made up.

Most agreed that the program should be offered during regular class hours, so as to facilitate and encourage student attendance. There was some concern expressed about counting the program hours as "credit" hours, based on the fact that the programs would be run by people who were not necessarily members of the faculty. In the end, the faculty decided that pre-empted hours would be made up at the end of the semester.

\section{c. What disclosures would be given to students about the program.}

Opinion ranged from those who felt that information to the students should be routine, corresponding to information given to students about any upcoming part of the curriculum. Others felt strongly that detailed disclosure was necessary to minimize de facto coercion.

\section{d. Who would be in charge of the program.}

The faculty insisted that the program be coordinated and supervised by a member of the faculty.

\section{e. The content of the program.}

The original draft of the Diversity Subcommittee goals and objectives for curriculum did not specify a particular format or content for the program. The faculty, however, designated that the NCBI format and approach should be used. The rationale for this specification was that many of the faculty were familiar with that program and felt comfortable with its content.

\footnotetext{
${ }^{7}$ Prof. Neil Hamilton, Memorandum to Faculty, Diversity Committee, May 10, 1991.
} 


\section{PLANNING AND PRESENTING THE PROGRAM}

\section{A. Planning and Preparation}

When the Dean asked me to supervise the program, I immediately asked Joni Bibelhausen to work with me. She had been coordinating the work of the NCBI Trainers Group. We agreed that we would work with the NCBI Trainers Group to plan the program. Early in August we sent notices to all of the faculty inviting them to join the NCBI Trainers Group in the planning process. ${ }^{8}$ We also worked with the Associate Dean C. Paul Jones in freeing time of several staff people whose participation we deemed to be critical to the success of the program. The resultant Trainers Group, consisting of six faculty, five staff and one student ${ }^{9}$, met regularly from August through October to plan and practice.

There were four key decisions to make in planning the program. These are described below.

\section{Scheduling.}

We made several decisions regarding scheduling. First, we decided that the workshops should be held around the middle of the first semester. We felt that early in the semester students are still somewhat dazed by the newness in law school, and later they are focusing on exams.

This decided, we chose dates in coordination with the legal writing program, picking two days immediately following the due date of the first major writing assignment.

Second, we decided that students would attend workshops section by section; that is, we decided to present four workshops, one aimed at each of the four first year sections. We made this decision for two reasons. We felt that there was a programmatic advantage to this format, since the students would know each other to some extent already, would be motivated to meet each other further, and, we hoped, the group process and commitment developed by the workshops would prove useful as the section moved through law school more or less intact. Also, we concluded that our commitment to presenting the workshops during regular class hours

\footnotetext{
${ }^{8}$ Our August 5, 1991 memo to the Trainers Group and the full-time faculty, stated: We are also extending this invitation to the entire full-time faculty (including those who were not in the trainers group.) We hope to make our planning process an open and inclusive one

${ }^{9}$ Joni Bibelhausen, Ann Iijima, Ken Kirwin, Mary Mahoney, Judy Lively, Curt Stine, Anita Weitzman, Ann Juergens, Kim Blair, Doug Heidenreich and Liz Carlson and Eric Janus
} 
required this decision since there is not sufficient overlap of class hours to permit "joint" regular class hour sessions.

Third, we decided that all of the workshops should be presented on the same day(s). This seemed likely to reduce confusion and avoid scheduling conflicts (some students cross sections for some classes).

Fourth, we determined that we would offer six hour workshops. The standard workshop format specified by NCBI is six hours, though they provide protocols for shorter versions. We had tried a four-hour version in the spring of 1991 and had wished that we had done the complete workshop. ${ }^{10}$ Only the full six-hour version contains the "speak-outs" which most who participate in the workshops consider to be their high point. ${ }^{11}$

Fifth, we concluded that the workshops would have to be offered on two days, because students have at most four hours of class per day. To maintain continuity, the days should be contiguous. Since part-time students have no classes on Wednesdays, we concluded that the workshops would have to be either Monday-Tuesday or Thursday- Friday.

Finally, we decided that make-ups for pre-empted classes would be scheduled by the individual professors whose classes had been pre-empted. This plan was a change from my initial intentions. The faculty resolution of May 1991 had specified that pre- empted classes would be made up at the end of the semester. My assumption had been that the college calendar would be modified to accommodate this mandate. When we began planning for scheduling, however, in August, we discovered that no such modification of the calendar had been made. Thus, we had no choice but to make up classes on an ad hoc basis.

Each of these scheduling decisions may have had some impact on the attendance at the workshops. That subject is discussed below.

\section{Notice to Students}

The faculty resolution approving the program directed that notice be given to students: "Students will be told in advance of the program that while the program is highly recommended, attendance is not required." Prof. Dan Kleinberger made inquiry of Dean Hogg about compliance with this provision; the Dean requested that I work with Prof. Kleinberger in

\footnotetext{
${ }^{10}$ The four-hour version omitted the "speak-outs", in accordance with the NCBI protocol. The participants in that session, mostly first year students, clearly wanted more depth than the four- hour version provided. We concluded that a full six-hour session with speak-outs would have been preferable ${ }^{11}$ See below for full description of the workshop format.
} 
developing the language for the notice. He requested that either of us let him know if we had questions about the process.

Professor Kleinberger and I approached the task with some common and some divergent goals. We both felt that the notice should not be written in a way that discouraged students' attendance. While I felt that the program was an effective one which was politically neutral, inclusive and non-attacking, he took on the advocacy for those who had some misgivings about the program or about the propriety of the school's offering the program.

The concerns some on the faculty had fell into the following categories:

- That some students might feel coerced (or embarrassed) into attending, participating, or remaining at the workshop.

- That some students might find the workshop's emotional content distressing.

- That some students might make truly voluntary disclosures at the workshop and then, afterwards, feel embarrassed.

- That the desired confidentiality of the workshops could not be guaranteed.

- That the particular political views of the workshop leaders might creep in.

- That workshop leaders, not being professionals, might have difficulty keeping the discussion "on track."

After consulting with Prof. Kleinberger, I drafted a proposed notice, with input from the NCBI Trainers Group. The draft incorporated a statement of benefits and risks. Prof.

Kleinberger drafted extensive proposed revisions. The proposed revisions addressed, among other things, the concerns described above. The original draft and the proposed revisions differed in the amount of detail devoted to describing the proposed risks, and in the emphasis placed on the voluntariness of the program ${ }^{12}$. In addition, the proposed revisions made

\footnotetext{
${ }^{12}$ For example, the original draft described the program as "optional" in the first paragraph of the notice, and contained the following paragraph in the body of the notice:

Your participation is enthusiastically invited but not required.

The faculty has voted overwhelmingly to make this program available to all first year students during regular class hours. Most of the faculty have themselves participated in these workshops. The faculty's approval is based on its judgment that the skills and understanding you can gain from these workshops are important elements of your legal education.

Participation in the program is not mandatory. Attendance will not be taken or recorded.
} 
suggestions (mostly stylistic) about how to describe the content and purposes of the program.

Prof. Kleinberger and I met several times to discuss language. We sent a redraft to the NCBI Trainers Group and the entire faculty. The final version was distributed on October 1 to all first year students attached to a cover letter from Dean Hogg. In the final version, we attempted to present a set of benefits and risks which appeared "balanced".

The notice was distributed in class to each of the four sections on October 1. About a week prior to this distribution, we had posted numerous posters around the school building notifying students of the upcoming Skills for Diversity program.

\section{Name, content, and leaders}

In its approval of the program, the faculty specified that the program should be "based on" the NCBI model. The NCBI Trainers Group made a number of decisions on the implementation of that instruction.

\section{a) Name}

The committee selected as a name for the program "Skills for Diversity." Previous workshops at the college had been called "Welcoming Diversity" and "Prejudice Reduction Training." The committee made its choice to emphasize the relevance of the training to the work of lawyers. The committee wanted to emphasize to students the need to be able to work successfully in diverse environments. It wanted to emphasize that aspect of the workshop which focuses on the development of skills to work collaboratively with others. Informal feedback about the title "Prejudice Reduction" had been somewhat negative. Some people felt that that name connoted a blaming or accusatory approach. The committee rejected the "welcoming

Although the faculty encourages attendance, it is firm that attendance be voluntary and that neither the faculty nor the school will take any adverse action against any student for nonattendance.

Prof. Kleinberger's proposed revisions would have added the following: No one is required to participate in any particular part of a workshop. Each person is free to leave at any time, without giving a reason or even stating that she or he is leaving.

Prof. Kleinberger proposed changing the language of the second paragraph of the draft as follows:

The faculty feels equally strongly, however that participation should be voluntary. YOU ARE NOT REQUIRED TO ATTEND ANY OF THE WORKSHOPS. ATTENDANCE WILL NOT BE TAKEN. NO ONE WILL BE CHECKING TO SEE WHO COMES AND WHO DOES NOT. NEITHER THE COLLEGE NOR ANY MEMBER OF THE FACULTY OR STAFF WILL TAKE ANY ADVERSE ACTION AGAINST ANYONE FOR NOT ATTENDING OR GIVE ANY PREFERENCE TO THOSE WHO DO ATTEND 
diversity" title for several reasons. First, though it has a positive, non-blaming ring, it is also somewhat abstract. It did not convey the notion that concrete, professionally useful information and skills would be available in the workshops.

\section{b) Content}

The committee also discussed the workshop contents. The faculty resolution specified that the NCBI approach be used. That approach is discussed in some detail below. The NCBI model is a flexible one which can be adapted to a variety of formats and time periods. As indicated above, we had offered the workshops previously in a variety of formats. Among the issues we discussed was whether we should include the "speak-out" portion of the workshop. That portion is the most personal and most emotional -- and has proven to be the most interesting and effective in developing a feeling of group cohesiveness and progress. It was the portion of the workshop that made us, as potential facilitators, feel the most vulnerable. We decided to include it for a number of reasons. First, we thought the benefits which would potentially flow from the shared experience of the speak-outs were worth taking the small risks associated with the emotions generated by the exercise. ${ }^{13}$ We felt that the ideas underlying the speak-outs were central to the workshops. Our experience in the spring with a workshop which had omitted the speak-out bolstered our evaluation. In that workshop, attended mostly by first year students, the group had affirmatively indicated a desire to "go deeper" into the issues than our non-speak-out format would have allowed. We improvised in that workshop in a way which allowed people to tell some of their own stories. On balance, however, we felt that the speak-outs were a more effective format. The NCBI protocol calls for leaders to offer to take the hand of the person giving the speak-out. Some of our leaders felt uncomfortable about doing this, and the group decided that each leader or pair of leaders could decide whether to use that part of the workshop.

\section{c) Leaders}

The NCBI Trainers Group made some attempts to reach out beyond its membership to encourage specific other people who had been trained to consider leading one of the workshops. In the end, however, we had only eight volunteers to lead workshops, the minimum number we needed to provide a pair of leaders for each of four sessions. We attempted to construct pairs which would advance the purposes of the workshops. For three of the four leader pairs, we were

\footnotetext{
${ }^{13}$ See below for discussion of the elements of the workshop and the theory underlying the workshop design
} 
able to match people with experience leading workshops with those who had no experience. Each of the pairs contained a faculty and non-faculty member, and each contained significant diversity.

\section{B. Description of Content and Purposes of the NCBI Workshop}

The NCBI approach seeks to help organizations "address issues of ethnic and religious pluralism and resolve internal organizational difficulties that stem from attitudinal and institutional racism, sexism and other forms of discrimination."14 The model seeks to help individuals become "sensitive and aware of cultural differences and ... competent in the skills of inter-group relations." It is a workshop model which focuses on relationships at a personal level, rather than at an institutional, historical or political level. It specifically eschews attitudes of "moral righteousness," because these only serve to "reinforce feelings of guilt and blame."15 Programs based on guilt and blame tend to "leave participants feeling more divided from each other and less hopeful than before." 16

On the other hand, the NCBI approach recognizes that issues of prejudice and discrimination are often difficult and risky.

A great challenge in doing anti-racism work is avoiding two extremes: if people are targeted and required to label themselves as racists, sexists, etc., they can quickly become defensive and thereby lost to the work; if the programs are too comfortable, the hard issues never get raised and the unaware racism goes unchallenged.

The NCBI approach attempts to chart a balanced course, helping people to "take risks and to raise tough issues without violating their own sense of integrity and self- worth." 17

The NCBI approach is broad-based. It focuses on "all visible and invisible differences," and is not simply limited to issues of racism, sexism and religious bias. Brown and Mazza explain:

One of the more controversial issues in prejudice reduction work on campuses today is whether to address a range of discrimination issues or to focus solely on racism. The concern of many anti-racism activities is that the inclusion of other issues can be used as a convenient tactic to avoid the more difficult work on racism. NCBI has found that the effectiveness of anti-racism work is actually enhanced by including a discussion of other institutionalized forms of discrimination. ... A common reaction from many people of color who have participated in the NCBI prejudice reduction programs that include a diverse range of issues is an expression of relief at knowing that they hare not the only

\footnotetext{
${ }^{14}$ Cherie Brown, Coalition Building: Transforming Inter-group Relations Within Organizatio

${ }^{15}$ Id., p.2.

${ }^{16} \mathrm{Id}$

${ }^{17}$ Id. at.6.
} 
ones who have experienced serious discrimination. ${ }^{18}$

The NCBI model is based on the observation that group identification (voluntary and involuntary) can be used for harmful as well as beneficial purposes. It assumes that the harmful use of group identification arises from a number of sources, including conscious and unconscious stereotyping or "mental recordings" and feelings of pain and anger which people feel because of their membership in groups to which they identify. People must be able to feel some pride in their own groups before they can begin to build solid relationships with others. Further, people are not open to hearing about the oppression or discrimination against other groups if they are feeling bad about the treatment of their own group or of themselves.

The NCBI workshop is designed to help improve the participants' ability to work with diverse others by teaching about these basic ideas and by demonstrating and engaging in a model for communication. The steps in a typical workshop, along with their purposes, are set out below:

- Introductions: Participants introduce themselves, and state the groups with which they personally identify. This brief exercise begins to show how many different "groups" are salient to people's identities. This idea is continued in the "up/down" exercise where participants stand as various types of groups are called out. Here, it becomes clear that "groupings" cut the population in a variety of ways and that commonalties as well as differences are numerous.

- First thoughts: Next, the group does a brief exercise to demonstrate the formation and existence of stereotyping. This "first thoughts" exercise asks participants to say their first thoughts as the name of a particular group (which each has chosen) is said. This exercise is done in pairs, in large measure in recognition of the sensitivity of the disclosures which are asked for. Most participants report experiencing some subjective difficulty in doing this exercise. Many report that they experience the feeling of censoring their thoughts, an experience which lends experiential credence to the notion of unconscious stereotyping.

- Group Identity Exercises: A series of exercises follows which is designed to guide the participants through an examination of some of the group-identities which are important to them. Participants first explore their own "internalized oppression" -- stereotypes

\footnotetext{
18 Brown and Mazza, at 5-6.
} 
and negative ideas they have about their own group. The NCBI theory is that this is a necessary step in building inter-group coalitions. Also, NCBI has found that airing negative feelings about one's own group allows many people more readily to express authentic pride in their own group. ${ }^{19}$ Feeling pride in one's own identity is an important step in building coalitions with other group

- Caucuses: The participants group themselves in "caucuses" according to group identities which they have identified as important and in which they have suffered some injury or discrimination. Each caucus meets and discusses the question, "What do you never again want others to say, think, or do toward your group?" The groups then report to the whole workshop.

The NCBI theory is that people mistreat others only after they have been mistreated themselves. Helping people to "identify and to heal the sources of their own mistreatment is the most effective intervention strategy, since it is directed at the origins rather than the symptoms of mistreatment." 20 This exercise also gives each person a chance to speak with others listening attentively. "Often it is impossible to listen to the painful experiences of others unless one is also afforded the opportunity to express one's own painful experiences."21

- Speak-outs: The NCBI model asserts that the "most effective communication of the impact of racism is through the sharing of personal stories." Thus, a cornerstone of the NCBI workshops is the speak-outs. In a speak-out, a member of the group is afforded the opportunity to tell the rest of the participants about a personal experience of discrimination. ${ }^{22}$ In a typical workshop, three or four individuals are invited to do a speak-out. Group leaders attempt to achieve some diversity among those invited, since one of the objects of the speakouts is to show that there are some commonalties among all persons in the experience of discrimination. The speak-outs are often quite moving for the observing members of the group, who feel the power of the personal story. The speak-outs often have a healing effect on the speaker, as well, who experiences some release of emotions which may been buried since the incident. ${ }^{23}$

\footnotetext{
${ }^{19}$ Brown and Mazza, at 10

${ }^{20}$ Brown and Mazza at 11

${ }^{21}$ Id.

22 The group leaders invite each speak-out participant privately, and with explicit assurances of voluntariness.

${ }^{23}$ In the NCBI model, the group leader offers to take the hand of the person giving the speak-out After
} 
- Role-playing: The NCBI approach is based on the theory that "effective behavioral change requires skill training." 24 Thus, the last portion of the workshop is a role playing exercise designed to help people learn how to "interrupt" or deal effectively with comments which are oppressive to an individual or a group. The role playing emphasizes the principles which underlie the entire workshop: respect for the individual, careful listening, the assumption that behind oppressive comments is either some unconscious stereotyping or "recordings" or some form of pain arising from the speaker's own oppression. Though the role play exercise is addressed expressly to the person desiring to "interrupt" oppressive comments, its lessons have broader application. Perhaps most importantly, it provides a model for accepting_criticism or comments about one's own behavior. The NCBI model assumes that feelings of powerlessness and hopelessness often underlie an individual's apathy about racism and sexism and other forms of discrimination. By teaching participants a concrete skill in this area, the NCBI hopes to break through the feelings of powerlessness and hopelessness, thus encouraging more people to work actively to eliminate oppressive behavior.

\section{EVALUATION}

\section{A. Goals of the evaluation.}

This evaluation sets out to measure several aspects of the Skills for Diversity Workshop Program. First, it seeks to assess the effectiveness of the workshop for those who attended. Ideally, it would measure the effectiveness of the workshop in reference to two sets of goals: Our institutional goal "of assisting [our students] in learning how to work effectively with diverse others in professional situations;" and the goals set out by the NCBI program itself. ${ }^{25}$ There is no apparent way to measure either of these other than to obtain the subjective impressions of the participants and the facilitators.

Second, it assesses the "outreach" aspects of the program, i.e., the methods used to invite

\footnotetext{
the person has completed his/her story, the leader asks the participant to grab his/her hands and shake them as the participant says what he/she would have liked to have said to the person doing the discrimination. The purposes of these "hand holding" experiences are to provide support during the telling of the story, and to help the participant vent some of the emotion and anger associated with the story. Some of the WMCL leaders did not feel comfortable with the hand-holding during the story-telling and thus omitted it. As is discussed below, a few of the participants in the Skills for Diversity Workshops indicated that they felt some discomfort with the hand-holding.

${ }^{24}$ Brown and Mazza at 14

${ }^{25}$ See discussion above at page 14
} 
students to the workshops and to facilitate their attendance.

Third, it assesses whether students reported feeling coercion or discomfort in connection with their decisions to attend or the participation in the workshops.

\section{B. Sources of Information}

I have used the following to gather information for this evaluation:

Participant survey: This was survey given to all participants of the October 1991 Skills for Diversity Workshops at the end of the workshop. Of the 33 who completed the workshop, 29 completed these surveys.

Facilitator survey: Each of the eight facilitators of the October 1991 Skills for Diversity Workshops filled out a survey form immediately after the workshop. These forms state, among other things, attendance information.

Full-class survey: About one month after the workshop, all members of the first year class were asked to complete a survey about the workshops. Of the 341 students in the first year class, 295 completed that survey. ${ }^{26}$

Survey of participants at previous NCBI workshops:_The College sponsored four NCBI workshops prior to offering the Skills for Diversity program. During the summer of 1991, we surveyed all participants in these prior workshops. The survey asked open-ended questions about strengths and weakness of the program, and asked respondents to assess how, if at all, they had benefited from their participation. Eighteen of the approximately 120 in this group returned the questionnaires.

Orientation Diversity Program Surveys -- 1990, 1991: These were surveys filled out by first-year students at the conclusion of the one and one-half hour Program for Diversity during the New Student Orientations in August 1990 and

${ }^{26}$ A comparison of the demographics of the full class versus those completing the survey is shown in the following table.

\begin{tabular}{|l|l|l|l|l|}
\hline Race & $\begin{array}{l}\text { Number in } \\
\text { first year } \\
\text { class }\end{array}$ & $\begin{array}{l}\text { - as percent } \\
\text { of entire } \\
\text { class } \\
(\mathrm{n}=341)\end{array}$ & $\begin{array}{l}\text { Number in } \\
\text { First Year } \\
\text { Class } \\
\text { Completing } \\
\text { Survey }\end{array}$ & $\begin{array}{l}\text { - as percent of } \\
\text { total surveys } \\
\text { completed } \\
\text { (n= 295) }\end{array}$ \\
\hline Black/African American & 17 & $5 \%$ & 12 & $4 \%$ \\
\hline $\begin{array}{l}\text { Asian (including East Asian } \\
\text { Indian) }\end{array}$ & 11 & $3 \%$ & 10 & $3 \%$ \\
\hline Hispanic & 12 & $4 \%$ & 7 & $2 \%$ \\
\hline Native American/Indian & 2 & $1 \%$ & 2 & $1 \%$ \\
\hline White/Caucasian & 299 & $88 \%$ & 226 & $77 \%$ \\
\hline Blank -- No designation & & & 37 & $13 \%$ \\
\hline Total & 341 & & 295 & \\
\hline
\end{tabular}


1991.

\section{College enrollment information.}

\section{Evaluation of Program Content}

\section{Participants' evaluations of the workshop.}

Of the 33 students who stayed through the entire workshop, 29 completed evaluation forms at the end of the program. The evaluation forms asked a series of open- ended questions. The first two asked the students to describe the "overall strengths" and "overall weaknesses" of the training. I reviewed each of the completed forms, and based on these two answers, assigned one of three summary ratings:

- Good, if the "overall strengths" were substantive and no substantial "overall weaknesses" were identified. ${ }^{27}$

- Mixed, if there were substantial strengths and weaknesses identified.

- Poor, if there were substantial weaknesses identified and no substantial strengths.

The ratings by participants were as follows:

TABLE 1. WORKSHOP RATINGS BY PARTICIPANTS.

\begin{tabular}{|l|l|l|}
\hline \multicolumn{1}{|c|}{ Rating } & \multicolumn{1}{|c|}{ Number } & \multicolumn{1}{c|}{ Percent } \\
\hline Good & 22 & 76 \\
\hline Mixed & 6 & 21 \\
\hline Poor & 1 & 3 \\
\hline
\end{tabular}

These numbers showed substantial variability section by section. Two sections had "Good" ratings of $100 \%$. One section had a "Good" rating of 78\% with "Mixed" being $22 \%$. One section had "Good" 30\%, "Mixed" 57\%, and "Poor" 13\%.

${ }^{27}$ For example, a number of forms listed the lack of widespread attendance, or lack of diversity in the group, as a weakness. I counted these as insubstantial weaknesses, not going to the design or execution of the program itself but to the outreach effort and response by students. 


\section{a) Strengths Identified:}

Many of the strengths which the participants identified related directly to the goals of the program. The comments fell into several categories: Those which identified practical or behavioral benefits in dealing with and understanding others; those which noted the inclusive nature of the program; those which noted the safe and welcoming nature of the program.

Many students identified practical or behavioral benefits of their participation ${ }^{28}$ :

- Strategies in dealing with bias when confronted with it. (M)

- Learning to work with prejudices in a way that promotes diversity. (M).

- How to respond to slurs, etc. (M)

- This will make me a better person, a better student, and hopefully, a better lawyer. (G)

- $\quad$ Process to seek resolution and enhance understanding. (G)

- I felt the personal stories had a strong impact on me. It made me more sensitive to other people's diversity/issue. $(G)$

- Tools to overcome fears of diversity.

- I liked being able to share people's personal experiences and learning new skills. (G)

Many students noted the inclusiveness of the program: these students perceived that the program tended to draw people together rather than to separate them:

- The program had a positive focus, avoided guilt-based objectives. (G)

- The course did not focus on only race relations but rather all encompassing.(G)

- I enjoyed the opportunity to get to know other classmates. (P)

- Hearing people sound like me. (M)

- The sharing of experiences from a diverse group which make me feel we all had a lot in common. $(\mathrm{G})$

- The personal interaction between us as we explored feelings about our own

\footnotetext{
${ }^{28}$ The parentheses after the comment indicates the overall rating I assigned to that student's evaluation.
} 
differences. (G)

- Hearing stories, interacting, being able to express my thoughts and feelings. (G)

Some students identified the safety and comfort of the workshop as it dealt with complex and sensitive issues:

- Warm, open facilitators -- well organized (informed) created an atmosphere of safety/support for participants to be able to be open and feelings and experiences. (G)

- The speak-out was very valuable.(G)

- It was a neutral and open exposure of diversity issues. You approached the issue in a non-threatening way.(G)

- The interaction; the non-threatening environment; the instructors. (G)

- Uncomfortable risks were handled extremely well. (G)

- Although the topics were emotional the manner in which they were treated was non-threatening. (G)

- Bringing up our emotions during the workshop was very powerful. (G)

\section{b) Weaknesses identified:}

Weaknesses identified by participants struck several themes: some students found the program ineffective for a variety of reasons; some disagreed with the approach they perceived to be imbedded in the program; one mentioned the emotions; several noted relatively minor matters about specific parts of he program.

One lengthy comment questioned the effectiveness of the program while expressing a hostility to this sort of workshop:

- I thought it was run like a psych group. A canned processed program. I thought the "recordings" were used to create an artificial sense of social issues. The rest of the workshop more or less was premised on the outcome of these issues. I thought it made the workshop forced and artificial. I attended so that I could say I did. I wanted to validate my own skeptical feelings about such workshops. They were validated. I don't know that I believe it appropriate to even have such workshops. I don't believe they accomplish anything. ${ }^{29}$

Other comments followed a similar theme:

\footnotetext{
${ }^{29}$ This comment is taken from an full-class survey, rather than from a participant survey.
} 
- It was not diverse. Very homogenous. Many of the exercises were affected. (M)

- The artificiality of the exercises and the role playing. They just seemed much too trumped up to be believed. [The speak-outs were] so artificial its almost comic. It really didn't seem that people needed or wanted to do this. [Role play] too artificial. (M)

- Much of the program seemed too basic. It made me feel like a 6th grader. I am really sorry I spent my time going to this program when my classmates were studying or enjoying themselves. I don't think I've learned too much from this format. I find it hard to believe faculty or staff who've attended his program found it to be enriching, enlightening or enjoyable. I'm surprised it was supported overwhelmingly by the faculty. My time is valuable and I would think faculty and staff realize this. For me, this program was not worth the time I invested. (P)

- Relate more to real life situations. Age diversity

- Somehow the air of artificiality must be gotten rid of and I think the only way that can be done is to truly have a widely diverse group. . . . Make this mandatory if you want a representative $x$-section. It's very difficult to talk about racism when there are not race minorities.

One comment suggested that for this student, the goal of inclusion did not materialize:

- Too much focus on self esteem. Why not more on building dialogue between different people -- bridging a gap.... More focus on skills toward cooperation w/in diverse situations. Less self-esteem building. (M)

Another suggested that perhaps there had been too much focus on bridge building and not enough on confronting difficult differences:

- I don't know perhaps more direct discussion and confrontation may have been constructive but this may have been too threatening to members causing unconstructive defensive postures to be raised. ... I think identification of the problem requires the framework of discriminated groups. But I think resolution needs to transcend group distinctions.

One comments suggested that the person was uncomfortable with the emotion and some of the participation:

- Handholding, anger venting, role playing. (M)

A number of comments focused on the timing, execution and attendance of the workshop.

- $\quad$ Too little time spent on skills part. (G)

- $\quad$ The sparse attendance (mentioned by a number of people).

- Some members were allowed too much rein in speaking to areas outside the topics.(G) 
- It was far too short.(G)

- Program should not be optional since regular class schedules are used. (G)

- At times it seemed too structured; some parts could have been more spontaneous.(G)

- Too short -- most of this wasn't new --- I've had quite a few of these types of things over the last 35 years! (M)

- I think some political analysis or social analysis would have helped us all to understand how and why we play out prejudicial behaviors. More discussion among the whole group was needed. We obviously craved it by the 2nd day. (G)

- At times slow. (G)

- The first day [all but the caucuses, speak-outs and role play] was a bit superficial. (G)

- $\quad$ Seemed to (sic) cheesey sometime. (M)

\section{c) Comments on specific aspects of the workshops:}

The evaluation forms asked for comments about each portion of the program.

Here is a sample of those comments:

\section{Introductions:}

- Appreciated that we weren't forced to open up too soon.

\section{First Thought:}

- Programmed to a result.

- Good. More time should be spent on recognizing these.

\section{Internalized Oppression/Pride/It's Great to Be:}

- Liked the combo. Interesting insights. (It's great to be) not very valuable. (several comments to this effect.)

- Important and well handled. Thanks.

- Good because it allowed to place ideas into perspective.

- $\quad$ PPride] very difficult for me.

- Affected; I pride myself on my personal relationships, not on my social orientation.

- $\quad$ Spend less time on these areas. 


\section{Caucuses:}

- Less effective.

- Limited me because I could not be part of the thought process.

\section{Speak-outs:}

- Superb

- Excellent -- the most effective and moving part of workshop

- I like the flexibility.

- Key component of the program.

- Very effective.

- Less formal would be best; no hand holding (several comments to the same effect about hand holding).

- Should be more focused on diversity struggles.

\section{Role Play:}

- More specific -- we were digressing by this time.

- Learned some new skills.

- Needed to be more extensive. Probably the most valuable skill builder, we needed more. (Several comments to this effect).

- Difficult

- Not so good.

- Too artificial.

- I found this to be most valuable component. I guess this is what I expected from the program.

- Great -- more of these skills.

- Effective in showing how to react to ignorant comments.

- Very effective and helpful.

- Easier in group than in reality but good chance to narrow approaches. I'll remember this.

\section{Suggestions for improvement/other comments:}

- Show benefit [of program] on first day.... [D]emonstrate to people the 
process so, that they won't be scared.

- All students, especially people training to be advocates, must learn and acquire the skills from this workshop. I also recommend that people who were not here today should be required to participate ....

- There should be some exploration in providing a mandatory program that discussed the need for diversity. (Several comments to this effect.)

- Encourage greater minority participation although I realize this may be difficult to do . Programs put on by minority groups to share their experiences and increase awareness of other groups.

- A full course (quarter) is required at the $\mathrm{U}$ of $\mathrm{M}$ for teacher certification. We should have similar requirements.

- Student led sessions.

- More promotion. Explain more about the structure of program goals and the skills people will learn.

- More attendance. (Common comment.)

- Excellent program. (Several comments to this effect.)

- Longer w/maybe more speakouts and caucuses. Seminars about a particular group or groups may be interesting and meaningful.

Whatever program you select (this one or some other) I feel should be mandatory. If the faculty feels its so important, let's make sure all the students get a taste.... I'm really sorry I spent my time going to this program when my classmates were studying or enjoying themselves. I don't think I've learned too much from this format. ... Whatever the problems Wm Mitchell has had in the past, do not necessarily apply to first year students. What efforts have been made to direct these programs at the people who need them? ... I don't have any ideas about other programs.. However, I would value individual speakers more than "workshop-format" programs.

\section{Reasons Participants Left the Program Early}

The evaluations analyzed above were filled out only by those students who stayed until the end of the workshop ${ }^{30}$.

As indicated above, 42 students initially attended the workshops. Thirty-three completed a workshop. Only those who completed the workshops filled out the participant's evaluation. In the evaluation instrument given to all first year students, we inquired about the reasons people had for leaving early. The data from that survey are presented in this section.

In the full-class survey, eight respondents stated that they had attended only a part of the

${ }^{30}$ Except as noted. 
workshop. These individuals gave the following reasons for their early departure: too long, lots of studying (2), too idealistic ${ }^{31}$, too busy (2). They had the following comments about the program: it was worthwhile, facilitators were excellent, some of the exercises were uncomfortable. None of the people who left early raised significant concerns about coercion, pressure or emotional distress. ${ }^{32}$

\section{Data from Participants in Previous Workshops}

These data are comparable to the data collected on the Survey of participants at previous NCBI workshops. ${ }^{33}$ Eighteen of about 120 participants returned this survey. Ofthe 18, all but one found strengths and benefits from the program. Six (33\%) found some significant weakness. One had an overwhelmingly negative reaction.

Respondents identified the following benefits and strengths: non-judgmental, building of community, useful skills in dealing with prejudice, became better listener, more self-awareness, learned about prejudice, openness, informality, seeing things through others' eyes, more aware of own prejudice, honesty, greater awareness of different socio-cultural backgrounds, greater understanding for relating to constituents on a professional basis, a greatly expanded feeling of what its like to be a member of a minority, listen more carefully to self, personal growth.

One student said, "Even for a reserved person such as myself, I thought the environment lent itself to uninhibited open dialogue. . . . Helped me try to recognize my paradigms and work on overcoming them."

Six respondents identified non-trivial weaknesses. These included: "it was only six hours ... and it seemed a little bit superficial," "emotional witnessing was impressive but also uncomfortable -- too much like group therapy," "too much of a program. People need to be able to take an issue and run with it . . even confrontation," "the program seemed to depend too much on minority testimonials."

\footnotetext{
31 This student's comments were as follows:

After first day I didn't attend. Unfortunately, the program was skewed to be unbiased, uncontroversial and a few other un's which in effect I feel, rendered the program ineffective....it was another exercise in idealism. There appeared to be a fear of repercussion if realism was introduced.... Wouldn't the mandatory program be better? In reality you're supposedly teaching us skills to allow effective negotiations in the real world. Real live interaction whether people like it or not (although controversial) would be more effective to gain real world practicalit

32 See below, at page 53 for discussion of coercion and pressure.

33 See above at page 18 .
} 
A student respondent wrote: "The diversity of the group itself and the ability we had to speak out and express ourselves [was a strength]. ... Self-examination was very enlightening to me. I know that I have a deeper respect for those that give some effect to life." This student wrote that the program was "still a bit threatening if you can believe it." He felt the program could be improved by "stress[ing] the positive aspects of diversity.

Of the 18 responses, only one was overwhelmingly negative about the program. This person, a faculty member, stated:

The training, with all due respect, was nothing more than a glorified encounter group. I felt offended by the trainers' efforts to get people to think and joke their way. It sort of reminded me of what it must have felt like during the Cultural Revolution in China. I was also bothered by the trainers' self-righteousness and their incessant efforts to get people to share personal stuff while they held their hand. ... Re-focus your attention on true diversity by abandoning race and sexual preference as criteria and concentrating instead on true economic disadvantage resulting in lack of educational opportunities.

In addition to these written evaluations, I have much informal, word-of-mouth information from participants. Many participants reported extremely positive reactions to the program. Two informal evaluations (both received second hand) were negative. One was from a faculty member who did a speak-out and later regretted it. The second was from a student who is black who did a speak-out and later felt angry about it.

\section{Assessment of Participant Reaction}

About three-quarters of those who attended the entire program were enthusiastic about it. Most of the others who attended found something significantly positive about the program. Conversely, about one-quarter of the participants found some significant weakness with the program.

Many of the strengths identified were related to the goals of the program. ${ }^{34}$ Thus, many of the participants mentioned the skills portion of the program, the non-threatening atmosphere and the bridges or links built by the sharing of personal stories. Similarly, a good number of the weaknesses mentioned related to the perceived failure of the program to go far enough in reaching the desired goals. Thus, a number of the participants commented that the program was too short, that not enough time was spent on skills, that the attendance was too sparse, or that the program was not "diverse" enough.

\footnotetext{
${ }^{34}$ This is also true for the evaluations of the participants of other NCBI workshops, as summarized above. See page 26 .
} 
Only three of the participant surveys leveled serious criticism at the basic structure and purposes of the program. ${ }^{35}$ One participant criticized the program for being "too basic." In this respect, she pointed particularly to the middle exercises regarding "group" identity. She indicated that the skill-building role playing was the "most valuable" and that she had expected more of that sort of work. Another described the program as "artificial" -- and indicated that the only way to get rid of the artificiality is to have a "widely diverse group." In contrast to the first person, this respondent found the role playing "too artificial." He also thought that the speakouts were "so artificial its almost comic." The third participant found many of the exercises "affected." He described some of the program as "programmed to a result" and "serv[ing] an agenda." For example, with respect to the pride section, he stated "I pride myself on my personal relationships, not on my social orientation."

There are several patterns which may be of significance in evaluating participant reaction to the workshops. First, though the overwhelming majority of participants in the workshops react positively, there is a small but not insignificant group of participants who voice objections. The objections seem to sound several themes:

- The "artificiality" of the program: this objection suggests that the workshop does not get at the true issues involved in diversity. The relatively rigid structure of the workshops seems to be related to this objection. The rigid structure curtails confrontation and spontaneous discussion of the real issues.

- The underlying assumptions of the program: The reliance on group identities and the notion of unconscious stereotypes strikes some participants as incongruent with their view of social relations. Some participants would prefer to think entirely in terms of individual relations, ignoring or downplaying "group" identifies -- while others would prefer to emphasize some "group" identities (e.g., social class or economic situation) rather than others (race or sexual orientation).

- The emotional content of the program: While the emotional content of the program has not been reported to be seriously distressing, some people who have participated in the program are uncomfortable with the more emotional parts of the program.

- The over reliance on or under presence of participation by persons of color: Two participants at prior workshops thought that there was an over reliance on the "testimonials" of persons of color in the workshops. In the current set of workshops, a number of people commented that there was a need for more minority participation in the workshops. ${ }^{36}$ I suspect that underlying these two

\footnotetext{
${ }^{35}$ See also the comments from previous NCBI participants, as summarized above, page 27.

${ }^{36}$ In fact, attendance rates for students of color were well above rates for whites. See Table 5. And minority students made up a greater proportion of the workshop participants (23\%) than of the first year class as a whole (10\%). See below, page 32.
} 
differing perceptions are divergent views of the nature of racism and race relations, and the relative responsibility of the majority and minority groups for working out those relationships.

It may also be of significance that the reaction varied considerably from section to section. This might suggest that the leadership of the workshops correlated with student reaction. One participant, a 41 year old woman who is Native American, wrote in the full-class survey:

I did attend. I wanted to see how WMCL would handle such a 1presentation, particularly in light of previous problems, re: Diversity. Was this going to be a program just meeting minimum standards and satisfy a requirement? I would not recommend the program--too watered down--need professional facilitators or at least facilitators more comfortable with the program. Hope you can "beef it up" in the future.

Good luck.

Many other students wrote comments which were favorable toward the facilitators. The reaction also varied considerably between day and evening sections. ${ }^{37}$

The approval ratings of the participants roughly matched the reasons given for attendance by participants $^{38}$ The following table compares these two numbers:

TABLE 2. COMPARISON OF PARTICIPANTS' REASONS FOR ATTENDANCE WITH PARTICIPANTS' EVALUATION OF PROGRAM.

\begin{tabular}{|l|l|l|}
\hline \multicolumn{1}{|c|}{ Valance } & \multicolumn{1}{|c|}{$\begin{array}{c}\text { Reasons for } \\
\text { attendance }\end{array}$} & \multicolumn{1}{c|}{$\begin{array}{c}\text { Evaluation of } \\
\text { program }\end{array}$} \\
\hline Positive & $23(62 \%)$ & $22(76 \%)$ \\
\hline Neutral/mixed & $10(27 \%)$ & $6(21 \%)$ \\
\hline Hostile/negative & $1(3 \%)$ & $1(3 \%)$ \\
\hline \multicolumn{2}{|c|}{ Source: Full-class survey; participants' survey. }
\end{tabular}

The significance of this apparent correlation must be tempered by the fact that the "reasons for attendance" were reported after attendance, and thus may have been retroactively influenced by the respondent's evaluation of the program. Nonetheless, it is possible that the reaction of a student to the program might depend to a certain extent on her or his pre-existing attitudes and expectations. This point was hinted at in a comment by a 41 year old Jewish woman who

\footnotetext{
${ }^{37}$ All of the mixed and negative reactions were from day sections. All evening section evaluations were positive.

${ }^{38}$ The data on "reasons" for attendance were gathered from the full-class survey. This survey used openended questions to solicit students' reasons for choosing to attend or not to attend the workshop. I classified the reasons given as "positive," "neutral/mixed," or "hostile/negative." For example, I classified reasons mentioning the value of diversity or the potential benefit to be derived from the workshop as positive. I classified as neutral those reasons which indicated that the student was "curious" about the workshop
} 
attended the program:

I wish more people could have taken part. I also got to know some people I had never met in our section which was really nice! Unfortunately the group was mostly upper middle class whites who already have liberal ideas and views. The people who could use a class like this were definitely not involved!

One must be careful not to overestimate the effect of pre-existing attitude. For example, a 25 year old man who is white and politically very conservative attended a workshop last year and was extremely enthusiastic about it, offering to help with future efforts. Another student, a fourth year white man who described himself as initially very closed minded and intolerant on matters of race, spoke to me forcefully in favor of mandatory work on this issue in law school. He stated that he has learned much and opened his mind in law school, and that his learning has come from others who are willing to talk with him in a non-blaming, non-attacking way. And 25 year old woman who is white offered positive reasons why she attended. Nonetheless, she left early and found some fault in the way the program was conducted:

I thought it would offer insight on how to deal with sensitive issues that other people deal with on a regular basis. (Racial discrimination, insensitivity to sexual preference, etc.) I had an appointment the next day that I couldn't change. Make it a more open exchange of ideas, without prompting by the leaders to reach specific responses.

\section{Evaluation of Outreach Efforts}

\section{Demographics of Participants}

Forty-two students attended the beginning of the workshop. Of these, 33 completed the entire workshop. The attendance for each section was as follows:

TABLE 3. ATTENDANCE AT WORKSHOPS AND ATTRITION, BY SECTION.

\begin{tabular}{|l|l|l|l|}
\hline Section & $\begin{array}{c}\text { Beginning } \\
\text { Attendance }\end{array}$ & $\begin{array}{c}\text { Ending } \\
\text { Attendance }\end{array}$ & \% attrition \\
\hline 1 & 16 & 12 & 25 \\
\hline 2 & 10 & 8 & 20 \\
\hline 3 & 6 & 3 & 50 \\
\hline 4 & 10 & 10 & 0 \\
\hline Total & 42 & 33 & 21 \\
\hline
\end{tabular}

Source: Facilitators' Post-workshop evaluations

Expressed as a percentage of the entire first year student body, beginning attendance was as follows: 
TABLE 4. INITIAL ATTENDANCE AT WORKSHOPS, BY SECTION, AS PERCENT OF TOTAL ENROLLMENT IN SECTION.

\begin{tabular}{|l|l|l|l|}
\hline Section & \multicolumn{1}{|c|}{$\begin{array}{c}\text { Total } \\
\text { enrollment }\end{array}$} & $\begin{array}{c}\text { Number } \\
\text { attending at } \\
\text { beginning }\end{array}$ & $\begin{array}{c}\text { Percent } \\
\text { attending at } \\
\text { beginning }\end{array}$ \\
\hline 1 & 107 & 16 & $15 \%$ \\
\hline 2 & 91 & 10 & $11 \%$ \\
\hline 3 & 78 & 6 & $8 \%$ \\
\hline 4 & 65 & 10 & $15 \%$ \\
\hline Total & 341 & 42 & $12 \%$ \\
\hline
\end{tabular}

Source: Registrar and Facilitators' Post-workshop evaluations.

The demographic make-up of attendees is shown in the following table ${ }^{39}$ :

TABLE 5. FREQUENCY DISTRIBUTION OF ALL STUDENTS AND ATTENDEES, BY RACE AND SEX

\begin{tabular}{|l|l|l|l|l|}
\hline Race and Sex & $\begin{array}{c}\text { Number in } \\
\text { first year } \\
\text { class }\end{array}$ & $\begin{array}{c}\text { Number } \\
\text { Attending }\end{array}$ & $\begin{array}{c}\text { Attendees as } \\
\text { percent of total } \\
\text { attendees (n=42) }\end{array}$ & $\begin{array}{c}\text { Rate of } \\
\text { attendance }\end{array}$ \\
\hline $\begin{array}{l}\text { Black/African } \\
\text { American }\end{array}$ & 17 & 6 & $14 \%$ & $35 \%$ \\
\hline $\begin{array}{l}\text { Asian (including } \\
\text { Pacific Islander } \\
\text { and Asian Indian) }\end{array}$ & 11 & 5 & $12 \%$ & $45 \%$ \\
\hline Native American & 2 & 1 & $2 \%$ & $50 \%$ \\
\hline Hispanic & 12 & 0 & $0 \%$ & $0 \%$ \\
\hline White/Caucasian & 299 & 28 & $67 \%$ & $9 \%$ \\
\hline & & & & $14 \%$ \\
\hline Female & 160 & 22 & $52 \%$ & $11 \%$ \\
\hline Male & 181 & 20 & $48 \%$ & $12 \%$ \\
\hline & & & & $100 \%$ \\
\hline Total & 341 & 42 & & \\
\hline
\end{tabular}

Source: Registrar and Facilitators' Post-workshop evaluations.

${ }^{39}$ The table is based on information from the registrar as of October 1991 information from the facilitators' post-workshop surveys. Subsequent tables are based on data from the full-class survey, which was completed by 295 of the 341 students in the class. 
TABLE 6. FREQUENCY DISTRIBUTION OF ALL STUDENTS AND ATTENDEES, AND RATE OF ATTENDANCE, BY AGE

\begin{tabular}{|l|l|l|l|}
\hline \multicolumn{1}{|c|}{ Age } & \multicolumn{1}{|c|}{$\begin{array}{c}\text { Number in } \\
\text { First Year } \\
\text { Class } \\
\text { Completing } \\
\text { survey }\end{array}$} & $\begin{array}{c}\text { Number } \\
\text { attending }\end{array}$ & Rate of attendance \\
\hline Under 30 & 195 & 16 & $66 \%$ \\
\hline 30 \& over & 72 & 18 & $24 \%$ \\
\hline Blank & 28 & 3 & $9 \%$ \\
\hline
\end{tabular}

Analysis: The numbers in the tables above are based on self-reporting by students in the full-class survey. They are subject, therefore, to some inaccuracy. ${ }^{40}$ With that caveat in mind, we can make the following observations. Though students of color make up only about 10 percent of the student body, they made up 23 percent of the attendees. Women make up 42 percent of the student body and 47 percent of the attendees. The rate of attendance for students of color, 26\%, compares to a rate of attendance for white students of $11 \%$. The rate of attendance for women was $14 \%$ compared to the rate of attendance for men of $11 \%$. The rate of attendance for people 30 and over was $24 \%$, compared to the rate for those under 30 of $8 \%$. Although older people constitute only $24 \%$ of the class, they made up nearly half of the attendees.

\section{Reasons why participants chose to attend.}

The full-class survey also gathered information about the reasons why people chose to attend. This information is as follows:

Of the 37 attendees who completed questionnaires, 27 reported that they chose to attend for reasons which affirmatively valued the purposes of the workshops ${ }^{41}$. Seven who attended gave reasons which I classified as "curious." One attended because of a perception that a professor wanted him to. And one reported attending for a reason which I classified as hostile to the purposes of the workshop: to "validate" his skeptical feelings about such programs. The following table shows reasons given for attendance by those who attended part and those who

\footnotetext{
${ }^{40}$ For example, although 42 people attended all or part of a workshop, only 37 students so indicated on their surveys

${ }^{41}$ E.g., "diversity important.
} 
attended all of the program:

TABLE 7. Summary of REASONS GIVEN by ATTENDEES FOR THEIR DECISION to ATTEND

\begin{tabular}{|l|l|l|}
\hline \multicolumn{1}{|c|}{ Reason(s) Given } & $\begin{array}{c}\text { As \% of Full-time } \\
\text { attendees (number of } \\
\text { students)42 }\end{array}$ & $\begin{array}{c}\text { As \% of Part-time attendees } \\
\text { (number of students) }\end{array}$ \\
\hline $\begin{array}{l}\text { Thought program } \\
\text { would be of benefit }\end{array}$ & $79(23)$ & $25(2)$ \\
\hline Felt coercion & $4(1)$ & $13(1)$ \\
\hline Curious & $18(5)$ & $38(3)$ \\
\hline Hostile & $4(1)$ & 0 \\
\hline
\end{tabular}

Source: Full-class survey.

Note that only one of the attendees indicated that he/she had felt any coercion about attendance. ${ }^{43}$

\section{Reasons why students chose not to attend}

As indicated above, persons of color and older persons were much more likely to attend the workshop than whites and younger people. Women were slightly more likely than men. Thirteen percent of day students and $11 \%$ of night students attended.

An overwhelming percentage of the students was aware that the program was being offered.

TABLE 8. RESPONSE TO QUESTION "WERE YOU AWARE THAT THE SKILLS FOR DIVERSITY PROGRAM WAS BEING OFFERED?"

\begin{tabular}{|l|l|l|}
\hline \multicolumn{1}{|c|}{ Response } & \multicolumn{1}{|c|}{ Number } & \multicolumn{1}{c|}{ Percent } \\
\hline Yes & 292 & 99 \\
\hline No & 3 & 1 \\
\hline
\end{tabular}

Source: Full-class survey.

A high percentage of the students indicated that they had read the brochure.

\footnotetext{
${ }^{42}$ Note that percentages add to more than $100 \%$ and number of students adds to more than total fulltime attendees because some students wrote more than one reason for attendance.

${ }^{43}$ See discussion below at page 53.
} 
TABLE 9. FREQUENCY DISTRIBUTION OF STUDENTS WHO READ AND DID NOT READ THE BROCHURE

\begin{tabular}{|l|l|l|}
\hline & \multicolumn{1}{|c|}{ Number } & Percent \\
\hline Read Brochure & 256 & 87 \\
\hline Not read brochure & 39 & 13 \\
\hline \multicolumn{2}{|c|}{ Source: Full-class survey. }
\end{tabular}

The students were asked the following question:

As you were deciding whether or not to attend the program, did you understand that the program was:

optional required

not sure

TABle 10. Student PeRception of Whether Program WAs Optional or REQUIRED, AS PERCENTAGES

\begin{tabular}{|l|l|l|l|l|}
\hline & Optional & Required & Not sure & No Answer \\
\hline $\begin{array}{l}\text { Attendees } \\
(\mathrm{n}=37)\end{array}$ & 92 & 0 & 8 & 0 \\
\hline $\begin{array}{l}\text { Non- } \\
\text { attendees } \\
(\mathrm{n}=258)\end{array}$ & 93 & 0 & 2 & 5 \\
\hline $\begin{array}{l}\text { All students } \\
(\mathrm{n}=295)\end{array}$ & 93 & 0 & 3 & 4 \\
\hline
\end{tabular}

Source: Full-class survey.

Students were asked the following question:

As you were deciding whether or not to attend the program, what was your understanding of the faculty's position about the program: 
Table 11. Student Perception of Faculty Position about the Program, As PERCENTAGES

\begin{tabular}{|l|l|l|l|l|l|l|l|l|}
\hline & $\begin{array}{l}0 \\
\text { Uncertain } \\
\text { Don't } \\
\text { Know }\end{array}$ & $\begin{array}{l}1 \\
\text { Faculty } \\
\text { was } \\
\text { against } \\
\text { the } \\
\text { program }\end{array}$ & 2 & $\begin{array}{l}3 \text { Faculty } \\
\text { was } \\
\text { neutral } \\
\text { about the } \\
\text { program }\end{array}$ & 4 & $\begin{array}{l}\text { 5 Faculty was } \\
\text { enthusiastic } \\
\text { about the } \\
\text { program }\end{array}$ & $\begin{array}{l}\text { Average } \\
- \text { All in } \\
\text { category }\end{array}$ & $\begin{array}{l}\text { Average } \\
\text { - All in } \\
\text { categor } \\
\text { y with } \\
\text { an } \\
\text { opinion }\end{array}$ \\
\hline $\begin{array}{l}\text { Attendees } \\
(\mathrm{n}=37)\end{array}$ & 14 & 0 & 0 & 30 & 27 & 30 & 3.48 & 4 \\
\hline $\begin{array}{l}\text { Non- } \\
\text { attendees } \\
(\mathrm{n}=258)\end{array}$ & 18 & 0 & 1 & 15 & 40 & 26 & 3.37 & 4.1 \\
\hline $\begin{array}{l}\text { All students } \\
(\mathrm{n}=295)\end{array}$ & 18 & 0 & 1 & 17 & 38 & 27 & 3.41 & 4.1 \\
\hline
\end{tabular}

Thus, there was almost no variation between attendees and non-attendees in their average perception of the faculty's position. Among non-attendees, $66 \%$ thought that the faculty was positive or enthusiastic about the program, while only $57 \%$ of the attendees had that perception. Almost none of the students thought that the faculty was opposed to the program.

Students were asked whether they "experience[d] any pressure or coercion regarding [their] decision about whether or not to attend the program." Those who answered "yes" were asked whether the pressure or coercion was directed at "encouraging" or "discouraging" attendance, or "both." Answers to the first question are displayed in the following table ${ }^{44}$ :

TABLE 12. STUdent ANSWERS TO QUESTION, "DID YOU EXPERIENCE ANY PRESSURE OR COERCION REGARDING YOUR DECISION ABOUT WHETHER TO ATTEND THE PROGRAM?"

\begin{tabular}{|l|c|c|}
\hline & Yes & No or No Answer \\
\hline Attendees (n=37) & $3 \%(1)$ & $97 \%(36)$ \\
\hline $\begin{array}{l}\text { Non-attendees } \\
(\mathrm{n}=258)\end{array}$ & $7 \%(17)$ & $93 \%(241)$ \\
\hline $\begin{array}{l}\text { All students } \\
(\mathrm{n}=295)\end{array}$ & $6 \%(18)$ & $94 \%(277)$ \\
\hline \multicolumn{3}{|c|}{ Source: Full-class survey. }
\end{tabular}

\footnotetext{
${ }^{44}$ The table is based on answers to the specific question about coercion or pressure. In the open-ended question about reasons for attending and not attending, five students gave reasons which I have interpreted as referring to coercion or pressure. Of those five, one attended the entire workshop and one attended a part.
} 
Those students who answered "yes" to the question about experiencing pressure or coercion were asked whether the coercion was directed at discouraging attendance, encouraging attendance, or at both. The 18 students who reported feeling some pressure or coercion indicated that the pressure they felt was directed towards encouraging their attendance. Three of the 18 reportedly felt pressure or coercion aimed at discouraging their attendance, as well. Only one person who attended indicated that he/she had felt pressure or coercion.

The students were asked to rate their "understanding of the purposes and content of the program" when making their decision about whether or not to attend. The scale given to the students ranged from 1 -- poor , 3 - good, to 5 - excellent. A 0 represented "no opinion."

TABLE 13. STUDENTS' ASSESSMENT OF THEIR OWN LEVEL OF UNDERSTANDING OF PURPOSES AND CONTENT OF PROGRAM

\begin{tabular}{|l|l|l|l|l|}
\hline $\begin{array}{c}\text { Level of } \\
\text { Understanding }\end{array}$ & attended & percent & $\begin{array}{c}\text { not } \\
\text { attended }\end{array}$ & percent \\
\hline 0 & 0 & 0.0 & 16 & 6 \\
\hline 1 poor & 2 & 5 & 16 & 6 \\
\hline 2 & 7 & 19 & 67 & 26 \\
\hline 3 good & 13 & 35 & 84 & 33 \\
\hline 4 & 10 & 27 & 56 & 22 \\
\hline 5 excellent & 5 & 14 & 19 & 7 \\
\hline Total & 37 & 100.0 & 258 & 100 \\
\hline
\end{tabular}

These results show that those who attended felt, on average, that they had a slightly better understanding about the program than did those who chose not to attend. The average score for those who attended, 3.24, was slightly higher than for those who did not, 2.8. ${ }^{45}$

The students were asked for comments about how the information could be improved. The majority of these comments suggested the need for more information about the contents and structure of the program (38\% of the comments) while 9 comments (13\%) pointed out a need for more information about the benefits or purposes of the program.

The survey asked students to answer the following question: "Why did you decide to attend or not to attend the program?" Eighty-seven percent of the students answered this question. Many students gave more than one reason for their choice. Thus, in the analysis of reasons

${ }^{45}$ The average score for those who did not attend, figured on the basis only of those who expressed an opinion, is 2.98 . 
given, percentages may add up to more than $100 \%$ (percentages are given as a ratio of students giving a particular reason to total students, rather than to total reasons given). I have analyzed the reasons for attendance in two ways. In reading the surveys, I attempted to capture and record the free form answers with some particularity. Thus, I distinguished between and separately recorded "had to work" from "spent time with family." In a second analysis, I collapsed all of the reasons given into 19 broader categories. In this latter scheme, both of the reasons given above would fit into the broad category "priority." The following table shows the broad categories I used, along with the types of comments which I classified in each. The table also shows the number of students who commented in each category, along with the percent of the entire group who did not attend (258) which that number represents ${ }^{46}$.

TABLE 14. REASONS GIVEN BY NON-ATTENDEES FOR THEIR DECISION NOT TO ATTEND:

Source: Full-class survey.

Total respondents $=258$.

Priority (146 Students; $57 \%$ of all respondents)

\begin{tabular}{|l|l|l|}
\hline \multicolumn{1}{|c|}{ Reasons } & \multicolumn{1}{|c|}{$\begin{array}{c}\text { Number of } \\
\text { Students }\end{array}$} & $\begin{array}{c}\text { As percent of all } \\
\text { Respondents }\end{array}$ \\
\hline Had lots of studying; used time to study & 58 & $22 \%$ \\
\hline Too busy & 30 & $12 \%$ \\
\hline Spend time with family & 17 & $7 \%$ \\
\hline $\begin{array}{l}\text { Wanted break from clases, wanted time } \\
\text { off }\end{array}$ & 13 & $5 \%$ \\
\hline Not that high on priority list & 10 & $4 \%$ \\
\hline Worked at job & 6 & $2 \%$ \\
\hline Relax & 3 & $1 \%$ \\
\hline Ill & 3 & $1 \%$ \\
\hline Went home & 2 & $1 \%$ \\
\hline Work full time & 2 & $1 \%$ \\
\hline No sparte time for optional education & 1 & $0 \%$ \\
\hline Not interested & 1 & $0 \%$ \\
\hline
\end{tabular}

${ }^{46}$ Note that there is a small possibility for inaccuracy in the main category percentages and numbers. A few students may have made more than one comment in a particular category. Both comments would be counted. Thus, the numbers in the table most accurately are described as numbers of comments, rather than numbers of students 
No need (44 students; $17 \%$ of all respondents)

\begin{tabular}{|l|l|l|}
\hline \multicolumn{1}{|c|}{ Reasons } & \multicolumn{1}{c|}{$\begin{array}{c}\text { Number of } \\
\text { Students }\end{array}$} & $\begin{array}{c}\text { As percent of all } \\
\text { Respondents }\end{array}$ \\
\hline Attended similar progra; training in job & 15 & $6 \%$ \\
\hline $\begin{array}{l}\text { Knew the information ; good } \\
\text { understanding of the issues }\end{array}$ & 9 & $3 \%$ \\
\hline Experience in diverse groups & 5 & $2 \%$ \\
\hline $\begin{array}{l}\text { Felt comfortable with own attitudes on } \\
\text { these issues }\end{array}$ & 5 & $2 \$$ \\
\hline As a minority, no need & 4 & $2 \%$ \\
\hline Exposure as undergraduate & 3 & $1 \%$ \\
\hline I don't need & 2 & $1 \%$ \\
\hline Program not necessary & 1 & $0 \%$ \\
\hline $\begin{array}{l}\text { Already went to orientation program on } \\
\text { diversity }\end{array}$ & 1 & $0 \%$ \\
\hline
\end{tabular}

\section{Ineffective (36 Students; 14\% of all respondents)}

\begin{tabular}{|l|l|l|}
\hline \multicolumn{1}{|c|}{ Reasons } & \multicolumn{1}{c|}{$\begin{array}{c}\text { Number of } \\
\text { Students }\end{array}$} & $\begin{array}{c}\text { As percent of all } \\
\text { Respondents }\end{array}$ \\
\hline Didn't see benefit & 15 & $6 \%$ \\
\hline $\begin{array}{l}\text { Disappointed with orientation program } \\
\text { on diversity }\end{array}$ & 8 & $3 \%$ \\
\hline Would not solve complex problems & 2 & $1 \%$ \\
\hline Too late to change people & 2 & $1 \%$ \\
\hline Non-diverse group & 2 & $1 \%$ \\
\hline Can't teach diversity skills & 2 & $1 \%$ \\
\hline Was it similar to orientation program? & 1 & $0 \%$ \\
\hline Those who need it would not come & 1 & $0 \%$ \\
\hline Not convinced it would be worthwhile & 1 & $0 \%$ \\
\hline $\begin{array}{l}\text { Attended similar programs which were } \\
\text { not worthwhile }\end{array}$ & 1 & $0 \%$ \\
\hline $\begin{array}{l}\text { Felt would not cover "true” issues of } \\
\text { diversity }\end{array}$ & 1 & $0 \%$ \\
\hline
\end{tabular}


Hostile (15 Students; $5 \%$ of all respondents)

\begin{tabular}{|l|l|l|}
\hline \multicolumn{1}{|c|}{ Reasons } & \multicolumn{1}{c|}{$\begin{array}{c}\text { Number of } \\
\text { Students }\end{array}$} & $\begin{array}{c}\text { As percent of all } \\
\text { Respondents }\end{array}$ \\
\hline $\begin{array}{l}\text { Looked like response to WMCL's past } \\
\text { problems }\end{array}$ & 3 & $1 \%$ \\
\hline Diversity stressed too much & 3 & $1 \%$ \\
\hline Join people don't segregate them & 2 & $1 \%$ \\
\hline $\begin{array}{l}\text { Felt would become forum for } \\
\text { "politically correct" }\end{array}$ & 2 & $1 \%$ \\
\hline Not a genuine effort by WMCL & 2 & $0 \%$ \\
\hline Tired of this issue & 1 & $0 \%$ \\
\hline $\begin{array}{l}\text { Seemed like school "had to" hold } \\
\text { program }\end{array}$ & 1 & $0 \%$ \\
\hline Sick of white male bashing & 1 & \\
\hline
\end{tabular}

Better Information (13 Students; $5 \%$ of all respondents

\begin{tabular}{|l|l|l|}
\hline \multicolumn{1}{|c|}{ Reasons } & \multicolumn{1}{|c|}{$\begin{array}{c}\text { Number of } \\
\text { Students }\end{array}$} & $\begin{array}{c}\text { As percent of all } \\
\text { Respondents }\end{array}$ \\
\hline $\begin{array}{l}\text { Didn't know the purpose; clearer } \\
\text { explanation of purpose }\end{array}$ & 7 & $3 \%$ \\
\hline Explain contents thoroughly & 2 & $1 \%$ \\
\hline Not enough information re content & 2 & $1 \%$ \\
\hline More p.r. on what can be gained & 1 & $0 \%$ \\
\hline Marketing was poor & 1 & $0 \%$ \\
\hline
\end{tabular}

\section{Class Cancellation (11 Students; $4 \%$ of all respondents}

\begin{tabular}{|l|l|l|}
\hline \multicolumn{1}{|c|}{ Reasons } & \multicolumn{1}{|c|}{$\begin{array}{c}\text { Number of } \\
\text { Students }\end{array}$} & $\begin{array}{c}\text { As percent of all } \\
\text { Respondents }\end{array}$ \\
\hline $\begin{array}{l}\text { Make ups difficult; no time with } \\
\text { makeups }\end{array}$ & 10 & $4 \%$ \\
\hline $\begin{array}{l}\text { Class rescheduling hard; don't cancel } \\
\text { classes }\end{array}$ & 1 & $0 \%$ \\
\hline
\end{tabular}

Discomfort (9 Students; 3\% of all respondents

\begin{tabular}{|l|l|l|}
\hline \multicolumn{1}{|c|}{ Reasons } & \multicolumn{1}{c|}{$\begin{array}{c}\text { Number of } \\
\text { Students }\end{array}$} & $\begin{array}{c}\text { As percent of all } \\
\text { Respondents }\end{array}$ \\
\hline "touchy feely" & 3 & $1 \%$ \\
\hline Uncomfortable with self-disclosure & 2 & $1 \%$ \\
\hline Uncomfortable with such programs & 2 & $1 \%$ \\
\hline Feared being called racist & 1 & $0 \%$ \\
\hline $\begin{array}{l}\text { Small group; didn't want to be expected } \\
\text { to share }\end{array}$ & 1 & $0 \%$ \\
\hline
\end{tabular}


Timing (6 Students; $2 \%$ of all respondents)

\begin{tabular}{|l|c|c|}
\hline \multicolumn{1}{|c|}{ Reasons } & \multicolumn{1}{|c|}{$\begin{array}{c}\text { Number of } \\
\text { Students }\end{array}$} & $\begin{array}{c}\text { As percent of all } \\
\text { Respondents }\end{array}$ \\
\hline Shorten the time period; too long & 3 & $1 \%$ \\
\hline Bad time & 2 & $1 \%$ \\
\hline Improve timing & 1 & $0 \%$ \\
\hline
\end{tabular}

Facilitators (4 Students; $2 \%$ of all respondents)

\begin{tabular}{|l|c|c|}
\hline Reasons & $\begin{array}{c}\text { Number of } \\
\text { Students }\end{array}$ & $\begin{array}{c}\text { As percent of all } \\
\text { Respondents }\end{array}$ \\
\hline Identity of presenters & 4 & $2 \%$ \\
\hline
\end{tabular}

Orientation (3 Students; $1 \%$ of all respondents

\begin{tabular}{|l|c|c|}
\hline \multicolumn{1}{|c|}{ Reasons } & $\begin{array}{c}\text { Number of } \\
\text { Students }\end{array}$ & $\begin{array}{c}\text { As percent of all } \\
\text { Respondents }\end{array}$ \\
\hline $\begin{array}{l}\text { Do not show x's and o's; boring; lost } \\
\text { people }\end{array}$ & 3 & $1 \%$ \\
\hline
\end{tabular}

\section{Better content (2 Students; $1 \%$ of all respondents}

\begin{tabular}{|l|l|l|}
\hline \multicolumn{1}{|c|}{ Reasons } & Number of Students & $\begin{array}{c}\text { As percent of all } \\
\text { Respondents }\end{array}$ \\
\hline Bring in outside professionals & 1 & $0 \%$ \\
\hline Increase diversity of groups; bring outsiders & 1 & $0 \%$ \\
\hline
\end{tabular}

\section{No reason given (36 Students; $14 \%$ of all respondents)}

The three most common reasons given for non-attendance were that the training was not perceived as being high enough priority (57\%), the respondents felt they had no need for the training (17\%) and they felt that the training being offered would be ineffective (14\%).

For example, the statement of a 31 year old white man in a day section reflects all three of these reasons.

Though I am sympathetic to your goals in providing the program I did not feel it was worth the investment of my time. I have for years interacted intimately with various cultures races sexes and sexual orientated persons. This message is important but the people most in need would not attend voluntarily nor would they accept it if forced to attend.

And a 22 year old white woman wrote:

The information was not very specific. We really only were told the topic/subject. I think it would be more helpful if the activities were better described. What were people were actually going to do????....I work in a very, very diverse environment and I am exposed to many cultures. I didn't feel the info given to us explained exactly the purpose, goals, activities, the workshop 
had to offer for the time involved.

And, a 27 year old woman who is black wrote:

I felt it would be very helpful to persons who never interacted with persons of different races and cultures and social backgrounds. I do not fit into that category and consider myself diverse.

This comment from a 25 year old man who is white was fairly typical:

It sounded like a great program but for many of us $n$ students who work a fulltime job and have other requirements, decisions and priorities must be set and then fortunately good opportunities are past up.

A fairly large number of respondents indicated that they felt they had no need for such a program. An example of such a comment is this comment of a 44 year old woman who is Hispanic.

I chose not to attend because I believe that as a minority member who has spent over 10 years working with a diverse client population (mentally ill adults from many racial and ethnic backgrounds), living most of my adult life in diverse neighborhoods and interacting with diverse populations that this was an experience I could afford to miss--and, no, I didn't think I should attend to help educate others about how it feels to be a minority member.

Only a small percentage (5\%) of the respondents expressed reasons which I classified as "hostile" to the idea of the training. An example is this comment by a 22 year old man who is white:

You wouldn't survive in the real world without skills for D....I was becoming weary of the same old theme. From the time I arrived this is all I have heard. Which is fine but enough....Pretend as if white males are still part of society.

Another student, who did not provide demographic information, wrote:

Because of programs such as this there's a futile attempt to try bringing diversity to WMCL. I got the feeling this program came into existence only after pressure from various minority groups; had they not spoken, WMCL would not have such a program.

A 27 year old student wrote:

I am aware of my own behavior. I will always conduct myself in a professional manner with regards to interactions of others. Regardless of color, sex, sexual preference. I am currently very sick of the white male bashing. I do not believe that I should be held accountable for anything that I have had no part of.

A 22 year old woman who is African-American wrote:

I felt the program was useless because no one can develop skills about diversity at this point in his or her life. ... I did not feel that the workshop was genuine on the part of WMCL. I felt WMCL was only doing this to put on a show that diversity's important to them when it's really not. 
An even smaller group indicated that they did not attend because of their notions that this sort of training would make them uncomfortable (3\%). A 27 year old woman who is white characterized the program as "touchy feely." She wrote:

I consider myself liberal and open-minded, but a private person and I had no interest in hearing strangers personal problems or experiences and I was more than hesitant to share my own. This was just not my type of thing.

Those who did not attend showed the following age-related differences in the reasons they gave for non-attendance. Younger respondents (under 30) were more likely to indicate discomfort than were older people (4\% vs. $2 \%$ ). In both groups, about $5 \%$ of the respondents gave an answer which reflected hostility to the goals of the program. The younger group was slightly more likely to feel that the program would be ineffective (13\% vs. 11\%). In both groups, slightly more than half of the group cited their priorities as a reason for non-attendance. The biggest difference in responses was in the category of reasons I classified as indicating "no need" for the program. Here, $31 \%$ of the older students, versus $13 \%$ of the younger students, gave this as a reason. ${ }^{47}$

The students were asked the following question:

If you did not attend the program: would you be interested in attending a sixhour workshop on skills for diversity in the future?

Answers, as percentages of non-attendees, are reflected in the table below:

\section{TABLE 15. NON-ATTENDING STUDENT INTEREST IN ATTENDING A SIX-HOUR WORKSHOP ON DIVERSITY, AS PERCENTAGES}

\begin{tabular}{|l|l|}
\hline \multicolumn{1}{|c|}{ Answer } & \multicolumn{1}{c|}{ Percentage } \\
\hline Yes & 17 \\
\hline No & 29 \\
\hline Unsure & 31 \\
\hline No Answer & 22 \\
\hline
\end{tabular}

Those who answered "yes" were asked, "What could we do to make it more likely that you would attend?"

\footnotetext{
${ }^{47}$ Note that older students were more likely to attend the session than were younger students. The juxtaposition of this statistic with that cited in the text presents an interesting problem of interpretation. Perhaps the meaning of these two together is this: Older students, being more experienced and perhaps more self-aware, are more likely to see the need or benefit of a program like this than are younger students. However, due to their greater experience, more of the older students may have had previous training or work experience in working with diverse groups
} 
TABLE 16. FACTORS CITED BY NON-ATTENDEES AS INCREASING LIKELIHOOD OF ATTENDANCE AT FUTURE WORKSHOP

Source: Full-class survey.

Timing (28 Students; $10 \%$ of all respondents

\begin{tabular}{|l|l|l|}
\hline \multicolumn{1}{|c|}{ Factors } & Number of Students & As Percent of All Respondents \\
\hline Shorten the time period; too long & 6 & $2 \%$ \\
\hline Summertime; vacation time & 5 & $2 \%$ \\
\hline Weekend & 4 & $2 \%$ \\
\hline Shorter blocks of time & 3 & $1 \%$ \\
\hline Do earlier & 2 & $1 \%$ \\
\hline Make part of orientation & 2 & $1 \%$ \\
\hline Improve timing & 2 & $1 \%$ \\
\hline $3^{\text {rd }}$ or $4^{\text {th }}$ year so more relevant to practice & 1 & $0 \%$ \\
\hline Later, after acclimation & 1 & $0 \%$ \\
\hline Beginning of the semester & 1 & $0 \%$ \\
\hline
\end{tabular}

Better information (9 students; $3 \%$ of all respondents)

\begin{tabular}{|l|l|l|}
\hline \multicolumn{1}{|c|}{ Factors } & \multicolumn{1}{c|}{$\begin{array}{c}\text { Number of } \\
\text { Students }\end{array}$} & \multicolumn{1}{c|}{$\begin{array}{c}\text { As Percent of All } \\
\text { Respondents }\end{array}$} \\
\hline Explain contents thoroughly & 8 & $3 \%$ \\
\hline Make ups difficult; no time with makeups & 8 & $3 \%$ \\
\hline More p.r. on what can be gained & 1 & $0 \%$ \\
\hline $\begin{array}{l}\text { Class rescheduling hard; don't cancel } \\
\text { classes }\end{array}$ & 1 & $0 \%$ \\
\hline
\end{tabular}

\section{Better Content (5 Students; 2\% of all respondents)}

\begin{tabular}{|l|l|l|}
\hline \multicolumn{1}{|c|}{ Factors } & \multicolumn{1}{c|}{$\begin{array}{c}\text { Number of } \\
\text { Students }\end{array}$} & \multicolumn{1}{c|}{$\begin{array}{c}\text { As Percent of All } \\
\text { Respondents }\end{array}$} \\
\hline $\begin{array}{l}\text { Increase diversity of groups; bring } \\
\text { outsiders }\end{array}$ & 2 & $1 \%$ \\
\hline Make it differenet from other programs & 1 & $0 \%$ \\
\hline Bring in outside professionals & 1 & $0 \%$ \\
\hline Less structure & 1 & $0 \%$ \\
\hline
\end{tabular}

Mandatory (5 Students; 2\% of all respondents)

\begin{tabular}{|l|c|c|}
\hline Factors & $\begin{array}{c}\text { Number of } \\
\text { Students }\end{array}$ & $\begin{array}{c}\text { As Percent of All } \\
\text { Respondents }\end{array}$ \\
\hline Make it mandatory & 5 & $2 \%$ \\
\hline
\end{tabular}


Encourage (3 Students; $1 \%$ of all respondents)

\begin{tabular}{|l|l|l|}
\hline \multicolumn{1}{|c|}{ Factors } & Number of Students & As Percent of All Respondents \\
\hline Give it more legitimacy & 1 & $0 \%$ \\
\hline Offer food & 1 & $0 \%$ \\
\hline Give less homework & 1 & $0 \%$ \\
\hline
\end{tabular}

\section{Earlier notice (3 Students; $1 \%$ of all respondents}

\begin{tabular}{|c|c|l|}
\hline Factors & \multicolumn{1}{|c|}{ Number of Students } & As Percent of All Respondents \\
\hline Longer notices; earlier notice & 3 & $1 \%$ \\
\hline
\end{tabular}

\section{No answer given (200 students; $78 \%$ of all respondents)}

By far, the most significant factor identified by the students as encouraging their attendance was the timing of the program. Almost half of those responding to the question (28/58) identified timing as a factor which would encourage their attendance. Improved information and changing the content of the program were identified as factors, as well, but together did not account for as great a portion of the students as did timing. For example, a 33 year old man who is white wrote:

... .I interpreted the medium to be "touchy-feely". Perhaps this works in some context, however the universality of this could be questioned. (I would be more likely to attend if the program were) [1]ess structured. Interaction in a less authority driven mode.

In answer to the question,"Should William Mitchell continue to offer programs such as the Skills for Diversity Program? "', students responded as follows

TABLE 17. RESPONSE TO QUESTION, "SHOULD WILLIAM MITCHELL CONTINUE TO OFFER PROGRAMS SUCH AS THE SKILLS FOR DIVERSITY PROGRAM? " (AS PERCENTAGE OF ALL STUDENTS, $\mathrm{N}=295$ ):

\begin{tabular}{|l|l|}
\hline \multicolumn{1}{|c|}{ Response } & \multicolumn{1}{|c|}{ Percentage } \\
\hline Yes & $57 \%$ \\
\hline No & $5 \%$ \\
\hline No opinion & $26 \%$ \\
\hline No Answer & $12 \%$ \\
\hline
\end{tabular}

Students answered the following questions a series of questions prefaced by the following introduction:

If William Mitchell continues to offer programs such as this:

a. Should classes be canceled to facilitate student attendance (as percent of all students, $n=295$ ). 
Table 18. Student Responses to Question, "Should Classes be Canceled" (ASPERCENTAGE OF ALL STUDENTS, N=295):

\begin{tabular}{|l|l|}
\hline \multicolumn{1}{|c|}{ Response } & \multicolumn{2}{c|}{ Percentage } \\
\hline Yes & 48 \\
\hline No & 26 \\
\hline No Opinion & 14 \\
\hline No Answer & 12 \\
\hline
\end{tabular}

TABLE 19. Student RESPONSES TO Question, "SHOULD THE PROGRAM BE REQUIRED OF ALL STUDENTS?" (AS PERCENTAGE OF ALL STUDENTS, N=295):

\begin{tabular}{|l|l|}
\hline \multicolumn{1}{|c|}{ Response } & \multicolumn{2}{c|}{ Percentage } \\
\hline Yes & 20 \\
\hline No & 56 \\
\hline No Opinion & 14 \\
\hline No Answer & 10 \\
\hline
\end{tabular}

Predictably, students expressed a variety of opinions on this subject. While most students felt that the program should not be required, others felt that their own comfort level with a program such as this would have been increased if it had been required.

A 25 year old white male day student, for example, wrote "Appreciated ability to decide whether to attend." A 22 year old white woman wrote: "I don't think you should ever require attendance. Some people may feel awkward."

Another student in the same section, 22 years old, white and male, said, "Make it mandatory! I would have liked to go but no one else said that they were going." And a woman who identified herself as gay related her reluctance to participate both to the lack of privacy and confidentiality and to the fact that the program was not required:

As a minority, I thought I was going to be somewhat on display -- there seemed to be no provision for privacy. The situation did not seem very safe or confidential. Its not my job or duty to teach other students about gay issues, but had the environment been more confidential and required of all students, I think I would have been more willing to. By not having it required, I think you're "preaching to the converted."

Another student, a 22 year old man who is white, chose not to attend because he "could better use [his] time." He continued: "If it were mandatory, I think it would be beneficial. Since it's not mandatory, most of us chose not to go." 
TABLE 20. Student ANSWERS TO Question, "ShOULD THE PROGRAM BE OFFERED AT SOME TIME OTHER THAN FIRST SEMESTER FIRST YEAR? (AS PERCENTAGE OF ALL STUDENTS, N=295):

\begin{tabular}{|l|l|}
\hline \multicolumn{1}{|c|}{ Response } & \multicolumn{2}{c|}{ Percentage } \\
\hline Yes & 36 \\
\hline No & 18 \\
\hline No Opinion & 33 \\
\hline N Answer & 13 \\
\hline
\end{tabular}

In response to the question "If yes, when?", 81 students of the 295 respondents (27\%) suggested a time.

\begin{tabular}{|l|l|l|}
\hline \multicolumn{1}{|c|}{ Suggestion } & Number of Students & Percentage of Respondents \\
\hline Second semester first year & 27 & $9 \%$ \\
\hline Second year & 14 & $5 \%$ \\
\hline Summertime; vacation time & 9 & $3 \%$ \\
\hline Make part of orientiation & 9 & $3 \%$ \\
\hline Later, after acclimation & 6 & $2 \%$ \\
\hline Do earlier & 4 & $1 \%$ \\
\hline Spring & 1 & $0 \%$ \\
\hline $\begin{array}{l}3^{\text {rd }} \text { or } 4^{\text {th }} \text { year so more } \\
\text { relevant to practice }\end{array}$ & 1 & $0 \%$ \\
\hline Orientation & 1 & $0 \%$ \\
\hline $\begin{array}{l}\text { In conjuction with } \\
\text { profesional responsibility } \\
\text { course }\end{array}$ & 1 & $0 \%$ \\
\hline Midweek & 1 & $0 \%$ \\
\hline Week prior to classes & 1 & $0 \%$ \\
\hline Offer when less work & 1 & $0 \%$ \\
\hline
\end{tabular}

Most of those expressing an opinion about timing agreed that the program should be offered later, either during second semester, second year, or even later than that.

Students were asked "What could we do to encourage more students to attend?' Of the 295 respondents, 111 responded to this question. The most frequently given responses were the following: 
TABLE 21. SUMMARY OF STUDENT RESPONSES TO QUESTION, "WHAT COULD WE DO TO ENCOURAGE MORE STUDENTS TO ATTEND?"

\begin{tabular}{|l|l|l|}
\hline \multicolumn{1}{|c|}{ Response } & \multicolumn{1}{|c|}{$\begin{array}{c}\text { As percent of } \\
\text { all } \\
\text { respondents } \\
(\mathrm{n}=295)\end{array}$} & $\begin{array}{c}\text { As percent of } \\
\text { those } \\
\text { commenting } \\
(\mathrm{n}=111)\end{array}$ \\
\hline $\begin{array}{l}\text { Provide better } \\
\text { information }\end{array}$ & 11 & 29 \\
\hline $\begin{array}{l}\text { Provide more } \\
\text { encouragement }\end{array}$ & 6 & 16 \\
\hline $\begin{array}{l}\text { Make it } \\
\text { mandatory }\end{array}$ & 6 & 37 \\
\hline $\begin{array}{l}\text { Improve or change } \\
\text { the timing }\end{array}$ & 13 & \\
\hline
\end{tabular}

Students were asked for "other comments". The following is a summary of those comments.

TABLE 22. SUMMARY OF STUDENT COMMENTS

Number of students making at least one comment: 51 out of 295 (27\%).

Favorable Comments (9 Students; 3\% of all responsdents)

\begin{tabular}{|l|l|l|}
\hline \multicolumn{1}{|c|}{ Comments } & \multicolumn{1}{c|}{ Number of Students } & As Percent of All Respondents \\
\hline Facilitators excellent & 1 & $0 \%$ \\
\hline $\begin{array}{l}\text { Thought it would be } \\
\text { worthwhile }\end{array}$ & 1 & $0 \%$ \\
\hline Chance to meet people & 1 & $0 \%$ \\
\hline $\begin{array}{l}\text { Glad to see div. ed.; thik the } \\
\text { issue is important }\end{array}$ & 3 & $1 \%$ \\
\hline It was worthwhile & 4 & $1 \%$ \\
\hline Program was good & 1 & $0 \%$ \\
\hline Eliminate “disclaimers” & 1 & $0 \%$ \\
\hline
\end{tabular}

\section{Class cancellation (13 Students; $4 \%$ of all respondents}

\begin{tabular}{|l|l|l|}
\hline \multicolumn{1}{|c|}{ Comments } & \multicolumn{1}{|c|}{ Number of Students } & As Percent of All Respondents \\
\hline $\begin{array}{l}\text { Make ups difficult; no time } \\
\text { with makeups }\end{array}$ & 11 & $4 \%$ \\
\hline $\begin{array}{l}\text { Class cancellation class } \\
\text { rescheduling hard; don't } \\
\text { cancel classes }\end{array}$ & 2 & $1 \%$ \\
\hline
\end{tabular}


Discomfort (3 Students; 1\% of all respondents)

\begin{tabular}{|l|l|l|}
\hline \multicolumn{1}{|c|}{ Comments } & Number of Students & As Percent of All Respondents \\
\hline $\begin{array}{l}\text { As a minority, didn't want to } \\
\text { be in spotlight }\end{array}$ & 11 & $4 \%$ \\
\hline $\begin{array}{l}\text { Did not enjoy the pride } \\
\text { sections of the program }\end{array}$ & 1 & $0 \%$ \\
\hline $\begin{array}{l}\text { Some of exercises } \\
\text { uncomfortable }\end{array}$ & 1 & $0 \%$ \\
\hline
\end{tabular}

\section{Hostile (5 Students; 2\% of all respondents)}

\begin{tabular}{|l|l|l|}
\hline \multicolumn{1}{|c|}{ Comments } & \multicolumn{1}{|c|}{ Number of Students } & As Percent of All Respondents \\
\hline Tired of the issue & 1 & $0 \%$ \\
\hline $\begin{array}{l}\text { Looked like response to } \\
\text { WMCL's past problems }\end{array}$ & 1 & $0 \%$ \\
\hline $\begin{array}{l}\text { WMCL treats minorities better } \\
\text { than whites }\end{array}$ & 1 & $0 \%$ \\
\hline $\begin{array}{l}\text { Done just to make the school } \\
\text { look better }\end{array}$ & 1 & $0 \%$ \\
\hline $\begin{array}{l}\text { Not a genuine effort by } \\
\text { WMCL }\end{array}$ & 1 & $0 \%$ \\
\hline
\end{tabular}

\section{Ineffective (3 Students; $1 \%$ of all respondents)}

\begin{tabular}{|l|l|l|}
\hline \multicolumn{1}{|c|}{ Comments } & \multicolumn{1}{|c|}{ Number of Students } & As Percent of All Respondents \\
\hline $\begin{array}{l}\text { Those who need it would not } \\
\text { come }\end{array}$ & 1 & $0 \%$ \\
\hline Non-diverse group & 1 & $0 \%$ \\
\hline Make it "real" & 1 & $0 \%$ \\
\hline
\end{tabular}

Make it mandatory (4 Students; $2 \%$ of all respondents)

\begin{tabular}{|l|l|l|}
\hline \multicolumn{1}{|c|}{ Comments } & Number of Students & As Percent of All Respondents \\
\hline Make it mandatory & 2 & $1 \%$ \\
\hline Integrate into classes & 1 & $0 \%$ \\
\hline Incorporate into every class & 1 & $0 \%$ \\
\hline
\end{tabular}

\section{No need (3 Students; $1 \%$ of all respondents)}

\begin{tabular}{|l|l|l|}
\hline \multicolumn{1}{|c|}{ Comments } & \multicolumn{1}{|c|}{ Number of Students } & As Percent of All Respondents \\
\hline Experience in diverse groups & 1 & $0 \%$ \\
\hline $\begin{array}{l}\text { Attended similar programs; } \\
\text { training in job }\end{array}$ & 1 & $0 \%$ \\
\hline Exposure as undergraduate & 1 & $0 \%$ \\
\hline
\end{tabular}




\section{Orientation (1 Student; $0 \%$ of all respondents)}

\begin{tabular}{|l|l|l|}
\hline \multicolumn{1}{|c|}{ Comments } & Number of Students & As Percent of All Respondents \\
\hline $\begin{array}{l}\text { Do not show x's and o's; } \\
\text { boring; lost people }\end{array}$ & 1 & $0 \%$ \\
\hline
\end{tabular}

Timing (8 Students; 3\% of all respondents)

\begin{tabular}{|l|l|l|}
\hline \multicolumn{1}{|c|}{ Comments } & \multicolumn{1}{|c|}{ Number of Students } & As Percent of All Respondents \\
\hline Summertime; vacation time & 1 & $0 \%$ \\
\hline Shorter blocks of time & 1 & $0 \%$ \\
\hline Do earlier & 1 & $0 \%$ \\
\hline Improve timing & 1 & $0 \%$ \\
\hline $\begin{array}{l}1^{\text {st }} \text { yr students too } \\
\text { overwhelmed to appreciate } \\
\text { importance }\end{array}$ & 1 & $0 \%$ \\
\hline Midweek & 1 & $0 \%$ \\
\hline Outside of class time & 1 & $0 \%$ \\
\hline Weekend & 1 & $0 \%$ \\
\hline
\end{tabular}

The most common comments in this section focused on the fact that canceled classes had to be made up, followed by positive comments about the program by those who had attended and comments about the timing of the program. On the issue of class cancellation, for example, one 26 year old white woman wrote:

I felt that if the program were so important it should have been done without requiring us to make up the class hours. With our time limitations it was almost like a punishment and I felt it created such a negative feeling that I had no desire to attend.

And a 26 year old white male in a day section commented:

I may be more likely to attend if we were not expected to "double-up on coursework" in order to make up for time lost. It is hard to motivate oneself for an optional program when there is this much work to do.

A 26 year old man from an evening section wrote:

I am far too busy to insert an extra 6 hours of class time--even for such an admittedly worthy program. If classes had been canceled (rather than rescheduled), the likelihood of my attendance would have been significantly greater.

\section{Evaluation of the Data on Outreach}

Several conclusions can be drawn from the data just discussed. Almost all students were actually aware of the program. Almost all understood that the program was optional. A large percentage had read the brochure describing the program. Most felt that the faculty was at least 
somewhat favorable toward the program. Very few indicated that they felt any sort of pressure or coercion about attendance. Of those who felt coercion or pressure in favor of attendance, almost none acted in accordance with the perceived pressure or coercion. Most felt they had a good or better understanding of the purposes and content of the program.

A small number of students (9/295) cited reasons for non-attendance which were related to the disclaimers given in the notice. For example, a 23 year old woman who is white commented:

I consciously chose not to attend the program because I felt that it would become a forum for issues, especially for those who are "politically correct" rather than a discussion about the diverse backgrounds of our class. ... Encourage all viewpoints, not just those that are politically correct. I do not feel that the atmosphere of this school is conducive to freedom of thought. The school, especially [a particular student] group is very hostile to those who promote "prolife" attitudes and lifestyles.

Another person, a 22 year old woman who is white, stated:

Based on the description of the program, I did not feel comfortable about coming to such a workshop where there was self-disclosure involved.

Especially when I would see the participants in class everyday.

A few students chose not to attend because they feared this program would have the same faults as other diversity programs they had attended in the past. A 23 year old man who is white said: :

I have attended several such programs in my undergraduate career. Many of these programs ended up being an uncomfortable experience where I felt I was put on the defensive because of any racial problem in society. This has left me with a bad taste in my mouth about such programs.

The most widespread reasons given for non-attendance were those related to the priorities of the students. Nearly 60 percent of the students gave this sort of a reply when asked why they decided not to attend. Fourteen percent did not attend because they felt this training would be ineffective. A 24 year old woman who is German American wrote:

I worked for three years in state government and learned a lot about these issues by dealing with people of different cultural backgrounds. I don't think two day workshop will change anything! You have to learn by experience or at an early age! 
The numbers suggest a relatively broad-based acceptance of the value of programs on issues of diversity. ${ }^{48}$ For many, the choice was not based on a devaluing of the purposes of the program, but rather on its relatively lower priority under the particularly circumstances of a first semester, first year student. For example, one student (a 22 year old woman who is white) who chose not to attend for priority reasons stated:

The idea of having two days off was more appealing than attending the program--although the program did sound interesting. Maybe have two hour blocks over a couple of weeks or a week and a half and have them in the morning or evening.

Another, a 27 year old man who is white, wrote:

As a panic stricken first year, I used the two days off to get ahead. I was interested in attending, but felt my schoolwork was more of a priority.

A third student, a 32 year old woman who is white, wrote:

Thought it was a balancing choice. My present need (to study) against future benefit (increase awareness).

Only 5 percent of the students affirmatively stated that programs like this should not be offered in the future. Fifty-seven percent affirmatively supported offering such programs. Further, there was wide support for canceling classes for such programs (48\%) though a significant minority disapproved (26\%).

Twenty percent of the non-attendees (17\% of the students) stated they would be interested in attending a workshop in the future. Thirty percent of the students indicated they would not. Thirty-one percent of the students indicated they were unsure. The most important factors identified by the students as possibly encouraging attendance focused on the timing of the program and on the type of information provided.

Older students and students of color were more likely to attend than younger and white

${ }^{48}$ These data are consistent with the data I have collected in connection with the College's diversity programs for New Student Orientation. At the conclusion of that 1.5 hour program, students answered a short evaluation form. One of the questions asked each student to rate the importance of "diversity" at an institution like William Mitchell. The question is clearly an ambiguous one in many respects, but the answers may provide some indication of student attitude toward workshops like the Skills for Diversity program. On a scale of 1 (lowest) to 5 (highest), the rankings for the 1990 and 1991 programs were as follows:

(As percent of total respondents)

\begin{tabular}{|l|l|l|l|l|l|l|}
\hline ranking: & 1 & 2 & 3 & 4 & 5 & no answer \\
\hline 1990 & $1 \%$ & 2 & 7 & 18 & 70 & 2 \\
\hline 1991 & 1 & 1 & 4 & 22 & 64 & 9 \\
\hline
\end{tabular}
Source: Orientation Diversity Program Surveys


students. Older students who did not attend were more likely to base their decision on the fact that they did not need the program than were younger students.

The conclusion I draw from all of this information is that many students decided not to attend the program for reasons having to do with their particular circumstances and their view of the program. In other words, the decision seems to have been made, in general, as a judgment of relative priorities. For a variety of reasons, the offered training was ranked lower in priority than other things (usually school, work or family). Older students and students of color may have been more likely to attend because the importance of such a program was more apparent to them than to others. Having grown up in a more socially aware decade, and having experience in the workplace, older students were perhaps more attuned to the notion that skills are necessary in a diverse work place. In being more aware, a significant percentage of them judged themselves not in need of the training, most often because of prior experiences or training.

Other facts support this conclusion. While 30 percent of the non-attendees said they would not be interested in attending a workshop, 31 percent indicated they were not sure. The large number of students who were unsure indicates that contingencies such as the nature of the program and competing demands for time may be important factors in determining attendance.

\section{E. Evaluation of Coercion, Pressure, Political and emotional Content, and}

\section{Warnings of Risk}

\section{Pressure and coercion as factors in attendance decisions}

As discussed above, pressure or coercive feelings were reported only by one or two students who attended the workshop. All of the other students who reported feeling some pressure or coercion chose not to attend.

\section{Political and emotional content as factors in attendance decisions}

There is no indication that political considerations played an important part in students' decisions about attendance. Five percent of the students stated reasons which focused on the "politics" of diversity. For example, a 24 year old woman who is white wrote:

I did not attend the program because the information provided suggested that the program conflicted with my philosophy about diversity. I believe that the goal of society should be to treat each person as an individual with their own set of traits and background--NOT to have everyone try to identify the common backgrounds of each minority group--because each person is different. 
Approximately the same number indicated that they had felt some coercion or pressure about attendance.

\section{Pressure, coercion, politics and emotion as perceived by participants}

There was no evidence in the data collected from participants that any of them found the program to be coercive or emotionally distressing. There was no evidence that students found participation, or non-participation, unusually difficult or embarrassing. There was no evidence that students felt significant constraints not to leave the program. No one reported being targeted or attacked or blamed or made to feel guilty.

There is evidence, however, that some students felt a moderate amount of discomfort. For example, one participant, a 25 year old woman who is white, attended the first day and did not return the second. She wrote:

I decided I would try the program the first day and if I didn't like it I would pass on the second day. I did not attend the second day although it was not as easy to skip as was described in the handout. I felt guilty for upsetting the group dynamics established in day one. I felt some of the exercises were uncomfortable. I was also involved in the phone-a-thon and I wanted to use this time to catch-up.

And, as reported above, two participants at prior workshops reportedly felt some regret or anger over their participation in the speak-out portion of the program.

More typical were positive comments by participants about the level of comfort and safety they felt when discussing difficult and sensitive topics. ${ }^{49}$

A small number of the participants made comments about the program which could be interpreted as objections to the "political" content of the program ${ }^{50}$ but none of those indicated that they felt silenced or oppressed by the political content. At most, one could say that the perceived contents of this particular program did not speak effectively to a small number of participants.

One student who attended and described herself as 35 years old, white, working class, made the following comment on the need for the disclaimers in the brochure:

\footnotetext{
${ }^{49}$ See above, page 21.

50 These comments suggested mixed perspectives. For example, one student commented that she/he left the program early because it was too uncontroversial and unbiased. Another student commented that he wished there were "some political analysis or social analysis." On the other hand, at least one student's comments seemed to be based on his objection to the use of "groups" -- "I pride myself on my personal relationships, not on my social orientation." Only one person (a participant at a prior session) seemed to think that there was too much emphasis on race in the workshop
} 
I was not pleased with all the "disclaimers" on the info. Made it seem like it might be scary, confrontative, threatening which it most emphatically is/was not .... Eliminate those obnoxious disclaimers that probably scared people away, (or I wonder--was that the object?) ... I I find it hard to believe some of the negative hostile attitudes I see here. ... I I get the feeling that some faculty is opposed, that administration is opposed and I'm grateful some faculty have the courage and dedication to do this. Again, even more needs to be done, why, oh why, is this so controversial? Humans are so goofy. 14D. Talk it up in class, in paper, in Docket.

Enough of this "objective"--let's get advocacy oriented. . . . Thank you!

\section{Assessment of pressure, coercion, political and emotional content and warnings of risk}

Student perception of faculty position on the program varied insignificantly from attendees to non-attendees. This suggests that faculty attitude about the program was conveyed fairly unambiguously, and that factors other than this perception played an important part in students' decisions about attendance. Students, in other words, appeared to exercise their independent judgments about attendance, taking into account factors other than (or in addition to) perceived faculty position.

The relatively low level of perceived coercion and pressure could be attributed to a number of factors. One hypothesis is that the disclosures on the brochure were a significant factor in producing such a low level of coercion. But, despite the disclosures, most students perceived that the faculty approved of the program and encouraged their attendance. That is, the disclosures were not enough to dissipate the message that the faculty recommended the program. One might say, then, that the "net" effect of the brochure was favorable to the program. Nonetheless, the coercive effect of this perception was negligible: even among those who felt faculty approval most strongly, attendance was minimal. Further, even those who felt pressure or coercion were able to resist. The pressure or coercion was apparently quite mild. For example, a 41 year old white woman who attended part of the program and then left stated:

I felt Professor wanted us to attend and that it must be awfully important since school was canceled. I felt responsible to attend or show up. I felt an obligation to go but had some responsibilities at home. (Explaining why she only attended part of the program). The idea is very worthwhile, the timing was wrong and more should go.

And a 24 year old woman was is white stated: "Although the faculty pushed us to go, I do not feel that we had enough interesting information to convince students to attend."

An overwhelming percentage of the students understood that the program was optional. 
This message got through even to those who said they did not read the brochure. ${ }^{51}$ In contrast, the level of understanding of the purposes and content of the program was more varied. Thirtytwo percent of those who did not attend felt their understanding of the program was less than good. These figures suggest that we need to put more energy into telling people about the program. On the other hand, disclosures about possible risks appear to be less needed.

\section{CONCLUSIONS AND RECOMMENDATIONS}

In this section, I set out the conclusions which I have drawn from the evaluation data and my recommendations for future programming in skills for diversity. My conclusions fall into the following categories: (a) the effectiveness and suitability of the program; (b) coercion, pressure, emotional distress, politics; (c) disclaimers, warnings of risk, content of notice; (d) level of attendance. In each of these areas I also set out my recommendations. Finally, I discuss the broader issues surrounding the place of skills for diversity training in the curriculum. I discuss whether the training should be part of the required curriculum. I examine issues of academic freedom, the diversity goals of the faculty, effective learning. I suggest a number of models for our future work in this area.

\section{A. Effectiveness and suitability of the program:}

The effectiveness and suitability of the program can be judged in a number of ways. Clearly, direct measurement of the accomplishment of its ultimate goals -- enabling the participants to work more effectively in a diverse work setting -- is not possible. Brown and Mazza do, however, cite some evidence that the NCBI program does effect some of the desired behavioral change among its participants. ${ }^{52}$

The subjective evaluations of those who participated provide a secondary source for valuation. A large majority (76\%) of those who participated found the experience positive and worthwhile and had no significant negative comments about it. Twenty-one percent had some negative comments, but found significant value in the program. Many comments indicated that the explicit purposes of the program were addressed for the participants in a meaningful and productive manner. That is, many of the participants observed that the program helped them feel

\footnotetext{
${ }^{51}$ Eighty-seven percent said they read the brochure, while 93\% said they knew the program was optional. No students thought the program was required. Three percent said they were unsure.

52 citation
} 
connections with others, helped them understand their own views on race, gender or other differences, or helped them learn some skills for dealing with prejudicial behavior.

There was a small, but not insignificant group, which felt less than entirely positive about the program. This group pointed to its artificiality, its highly structured nature, its emotional content and its lack of diversity.

Because the participants in the workshops were self-selected, there is a possibility that the distribution of reactions in a less self-selected group would be different. Indeed, there appeared to be a rough correlation between the attitudes participants brought into the workshop and their reactions to the workshop.

The evaluations varied from group to group. The variations could have been due either to differences in the leadership of the groups, to differences in the make-up of the groups, or to some combination of the two. The workshop groups were quite small; thus, one or two participants who felt less than positive about the workshop could have had a large influence on the group process.

From the data we can draw the following conclusions:

- The NCBI model is perceived to be an effective model by a large percentage of students who participate on a voluntary basis.

- The College has the internal resources to run the workshops effectively.

- The model is perceived as ineffective by a small but not insignificant portion of students who participate voluntarily.

- The small size of the workshop groups and the leadership of the groups may have some effect on participants' evaluation of the workshops.

- Students who participate involuntarily might evaluate the program differently.

\section{B. Coercion, pressure, emotional distress, politics}

There was no suggestion in the comments that students had been harmed or distressed by their participation. There was no suggestion that students felt silenced or oppressed by the program. Only a very few perceived the program to be politically motivated or oriented. Those who attended did not report the kind of embarrassment or emotional distress which the 
disclaimers warned of. None of those who left early identified these as factors in their decisions to leave.

There are several possible explanations for the absence of reported negative effects of the program. The NCBI program is designed specifically to avoid just these sorts of negative effects of participants. In fact, a number of the participants commented specifically and positively on this aspect of the program. Thus, one explanation for their absence lies in the design and execution of the program. It is also possible that disclaimers and warnings of risk allowed students who are sensitive to these matters to choose not to attend. Also, it is possible that the fact that students affirmatively chose to attend and were not required to attend made the students less sensitive to this kind of effect.

Perceptions of coercion and pressure and politics seemed to play only a minor role in the workshops and in attendance decisions. Few students felt coercion or pressure, and almost none was apparently influenced in his or her attendance decision by such perceptions.

\section{Disclaimers, warnings of risk, content of notice}

These data suggest that, in the future, we need not provide disclaimers about the program which characterize the "risks" of the program as graphically as we did this year. No endeavor can be wholly free of risk. Nothing that we as a faculty do (or omit doing) can be wholly free of persuasive or coercive effect. Rather, we should shape our programs so as to bring the risk and coercive effects into acceptable ranges.

The data suggest that the existing program is indeed within an acceptable range. The risk of emotional upset, of being targeted or humiliated, of being subjected to political manipulation is -by design and by report -- not substantially greater in this program than in the law school classroom. In fact, one could say that those risks are substantially less in this program than in the classroom.

This suggests that even if the program were made a part of the required curriculum concerns about coercion would not rest on a solid base. However, student concerns about coercion might increase if the program becomes mandatory.

Concerns about coercion should be addressed in two ways. First, our information to students should stress concrete and factual information about the content and methods of the program and its intended professional benefits. Concrete information will allow students to judge for 
themselves whether there are risks which are unacceptable.

Second, we should provide a variety of types of programs so that we are more likely to match students with programs they will find useful and effective. Allowing students to choose from among a variety of programs should moderate negative attitudes which stem from a feeling of coercion. Further, a variety of programs will allow students to choose programs which speak to their own perception of their interests, needs and preferences.

\section{Level of attendance}

The rate of attendance at the Skills for Diversity Workshops was exceedingly low. The low rate is a problem for several reasons. First, it indicates that the faculty objective in offering the program is not being accomplished. Second, it can be seen as a "failure" and this perception may influence the way in which members of the school community view issues of diversity and the school's efforts in that area. Finally, and relatedly, the program required a substantial amount of time and energy, and the cancellation of classes entailed a moderately significant disruption of the school routine. Clearly, as an initial, experimental attempt to provide a program on diversity, the investment of time and energy was worthwhile. However, one might legitimately question whether a similar expenditure of resources over the longer term would be justified by such a low rate of participation.

A key part of the decision about the future for a skills for diversity program involves a consideration of the level of participation. I perceive three alternatives.

Option 1: If we are satisfied with the level of participation achieved this year we should probably offer a similar program next year without class cancellation. Our experience last year shows that we can achieve approximately the same participation without the cancellation of classes and the concomitant disruption and expenditure of resources.

Option 2: If we wish universal, or nearly universal, exposure to the issues of diversity, we should include a skills for diversity program as part of the core curriculum.

Option 3: If we wish to have a significantly larger attendance than we had this year, but are satisfied with less than universal coverage, we could retain the basic structure of this year's program (optional attendance, cancel classes), but attempt to improve attendance by modifying the program in light of the lessons learned from this year's experience.

In my judgment, option 1 is incompatible with the positions the faculty has taken on 
diversity education. I thus do not explore it further here.

I discuss option 3 (making diversity education a part of the core curriculum) below. First, however, I turn to option 2.

\section{E.. Attaining maximum participation with an optional program during class time.}

With proper adjustments in timing and in the information provided to students, attendance could probably be increased beyond the $12 \%$ figure attained this year. While it impossible to say what level of attendance we could expect, the pool of students who are potentially receptive to a voluntary program of this sort probably exceeds $45 \% .^{53}$

The biggest factor influencing attendance was the students' perception of their priorities and of their lack of need for such a program. This suggests that attendance at an optional program could be increased if we raise the priority of this program relative to the other priorities of the students. This could be done by demonstrating more effectively the need for and usefulness of the program, and by lessening the competing demands on students.

In the future, information about the program should be improved by:

- Describing the program and its purposes more concretely for students.

- Providing information to students about the usefulness and necessity in law practice of the skills taught.

- Involving students and practicing lawyers in the recruitment process.

- Providing enough information to differentiate this program from others which students may have attended in the past. This information should emphasize the inclusive, non-threatening, non-blaming and non-lecturing nature of the program.

- Avoiding characterizing the "risks" of the program in ways which suggest that the risks of the program are more severe in magnitude and nature than the risks which students in a law school environment generally face. Rather, we should provide concrete information about the content of the program so that students can judge and characterize the risk for themselves.

A key to increasing attendance is scheduling which minimizes conflict with school work and

\footnotetext{
${ }^{53}$ I arrive at this figure in this way:

$12 \%$ attended

$17 \% \quad$ indicated they would be interested in attending.

$29 \%$
}

Thirty-one percent indicated they were not sure about future attendance. Of those, a large group (57\% of the entire class) indicated that they did not attend for reasons of priority. Thus, I estimated that about half of those who were "unsure" would attend under the proper circumstances. 
employment. Canceling classes, without make-ups, appears to be the best approach to easing the disincentives and barriers to attendance. However, as long as a great majority of the students choose not to attend, class cancellation remains problematic: It raises fairness and efficiency issues, and students may perceive a competitive disadvantage to using this otherwise free time for the workshop. If the workshop is held during regular class hours, pre-empted classes should not be made up. That is, the "break" for the workshops should be built in to the semester. One key factor in increasing attendance is to lessen the time pressure on students who participate. Requiring missed classes to be made up places increased pressure on attendees as compared to non-attendees. ${ }^{54}$ It also emphasizes the "add-on" and non-central nature of the program.

A second factor influencing attendance appears to be the timing of the program. Survey data suggest that mid-first semester of the first year is not an ideal time. The data suggest that the second semester of the first year might be better. Perhaps the second or third week of the second semester would be best. If possible, the workshops should be offered mid-week, to eliminate the incentive for students to take the time for a long weekend.

An additional way to boost attendance would be to offer students a variety of programs. A small but not insignificant number of participants did not like the format of the NCBI program. A small number of students indicated that their reasons for not attending were related to the particular format of the program being offered. These data suggest that attendance could be increased by offering alternate programs which addressed the concerns raised by these students. These programs might be characterized by:

- $\quad$ lower emotional or affective content than the NCBI approach

- $\quad$ less structured than the NCBI program

- $\quad$ less participatory than the NCBI program.

\footnotetext{
${ }^{54}$ Note that saying that classes should not be "made up" is not the same as saying that the normal number of class hours for a given subject should be reduced. Reduction of class hours is one alternative. Adding hours on to the semester is a second. In any event, the key is to avoid adding on extra hours in any given week in order to make up for the workshops.

Of course, there is relatively more pressure on attendees than on non-attendees even if pre-empted classes are not made up, simply because the non-attendees could use workshop time to get ahead or catch up on work otherwise assigned.
} 


\section{F. Mandatory versus optional: Academic Freedom, Coercive Learning and Effective Education}

The faculty must decide whether issues and skills of diversity -- inclusion and exclusion, race, gender, and other forms of "difference;" privilege, stereotypes, conscious and unconscious assumptions and biases; etc. -- should or must be a part of every lawyer's training and education. The importance we place on these issues will determine whether they should be close to the center, or towards the periphery, of the curriculum.

Curricular choices do, of necessity, entail choices of value, world view, politics and power. By omitting matters from the curriculum, we choose just as surely as when we require them of all students.

We must recognize that a diversity of views on all matters, especially those as complex and sensitive as race, gender, etc. is not only protected by the concept of academic freedom, but also a necessary ingredient of a healthy and creative approach to solving these societal problems.

Further, basic educational theory ought to tell us that there is no single pedagogy, no unique approach, which will be effective with all students. Students can be expected to respond in a variety of ways to any approach to the subject of diversity. Our task, as educators, is to find approaches which effectively speak to as many of our students as possible. Approaches which students perceive as coercive may do little to speak to those students.

On the other hand, silence on certain matters can be powerful. By failing to expand the space of choices students can perceive and act on, we help produce powerful agents of the status quo.

There is, of course, a tension between the institutional goals related to diversity, on the one hand, and the ideas of academic freedom and diversity of thought on the other. One can argue that this tension is not different in kind from the tension which inhabits all aspects of the curriculum. It is, perhaps, more intense because the politics of the choices are more visible and more intensely debated.

We can approach the tension in this area in the same basic way we approach it in others: As an institution, we make broad judgments about what areas and issues we wish addressed in the curriculum; we decide whether the areas are important enough to be mandatory or elective. Generally, we then leave questions of method and approach to each individual instructor. If we are lucky, a variety of instructors brings a healthy diversity of points of view to the common 
subject. Properly informed, each student can choose an approach which speaks most effectively to him or her.

As a faculty, we have already adopted goals and made choices in this area. These goals are:

Increasing the level of understanding, among all segments of the community, of the nature and history of racism, sexism, homophobia, religious intolerance, age and disability discrimination, and of the value to the institution, the profession, and the society of decreasing and eliminating these forms of intolerance and of increasing diversity.Incorporating into the curriculum significant and meaningful materials on the relationship of law to race, gender, sexual preference intolerance and bias, religious intolerance, age and disability discrimination and their eradication.

These are not "neutral" goals. They speak to the "decrease" and "elimination" and "eradication" of discrimination, intolerance, bias and the "increase" of "diversity." It seems to me that these goals bespeak our desire, as a faculty, to insure that all of our students are exposed to these issues in an effective manner. I conclude that this goal can best be accomplished by including materials addressed to the goals in the core curriculum presented to all students. At the same time, we should recognize the need for and desirability of a diversity of approaches.

\section{G. Models for Incorporating Diversity Education into the Core Curriculum}

Here, I present three models which incorporate diversity issues into the core curriculum, yet leave room for a variety of approaches to the subject.

It is critical to note that each of these models depends, for its success, on substantial commitment from the faculty. Model III assumes the development of a segment for a required course on the lawyering process. Models I and II assume that a substantial number of faculty will develop mini-courses or programs for students.

Without such participation, the promise of a diversity of approaches will be unrealized, and that will have consequences for those concerned about mandating a particular approach.

All three of these models assume a lead time of at least a year, and the allocation of resources to allow and encourage faculty to develop the required materials.

\section{Model I. A "CLE" Approach.}

We would require that each student engage in at least a given number of class hours addressed to issues of race, gender, sexual orientation, religion, disability, and other "difference" as they relate to law and the practice of law. As a school, we will commit to providing a variety of ways for each student to meet that requirement. Some would be "training" such as the NCBI 
Skills for Diversity Program. Others would be lectures, such as Bob Terry's or Richard Wasserstrom's. Some might be incorporated into classes, such as a unit in Work of the Lawyer or Civil Practice. The requirement could be based on CLE-style reporting. We might have subcategories of the requirement (e.g., so many hours must be devoted to interpersonal skills), and we might insist that the requirement (or parts of it) be met by particular milestones in a student's education.

\section{Model II. Bridge}

Under this model, a set period of time, probably six class hours, would be set aside in the first year curriculum for a "Diversity Bridge." Given our learning from this year, the best time would probably be the middle of the second week of the second semester. We would offer a variety of options for the students. The NCBI model could be one of several they could attend. Faculty members would be free ${ }^{55}$ to develop other approaches to the issue. Students could spend the six hours in one option (e.g., the NCBI), or could attend several shorter seminars or panel discussions on the subject of difference and diversity. Students would "register" in advance, making choices based on a mini-catalog of options.

We should treat the program as we treated the Bridge program several years ago: it is a regular part of the curriculum, held during regular class hours. The format and content, however, are different from regular classes. Issues of coercion and pressure should be ameliorated by making available a range of options for students. This model would require a commitment from a number of faculty to participate.

\section{Model III. Integration into a required "lawyering skills" course}

A third model would integrate issues of difference into a course designed to teach the interpersonal skills of lawyering. At present, the most logical place for this subject would be the Civil Practice course, a course which is not required. An alternate approach would be to include a unit on diversity in a revamped course on lawyering skills. An advantage of this model is that it would insure that all students were exposed to these issues, it would treat the issues as a by placing them within the core curriculum, and it would help emphasize the functional relationship between these issues and professional practice. However, the exposure would not take place until late in a student's career at Mitchell.

\footnotetext{
${ }^{55}$ Ideally, faculty members would be encouraged and facilitated in these efforts through the provision of faculty development programs and resources
} 


\section{H.. Extra-curricular training}

The availability of the NCBI-based workshops over the past 18 months has been a valuable part of the college's growth. The workshops appear to have been beneficial in a number of ways and to a number of segments of the college community. Whatever is decided about curricular changes, I recommend that the College maintain its extra- curricular training efforts.

Clear institutional lines of authority and responsibility should be established for future work in this area. The chosen arrangement should be adapted to the choices made by the institution and faculty about models and approaches. While curricular choices should be designed by faculty, coordination and implementation of extra-curricular training could continue to be an administrative responsibility. 